\title{
DECOUPLING BETWEEN HUMAN DEVELOPMENT AND ENERGY CONSUMPTION WITHIN FOOTPRINT ACCOUNTS
}

\author{
Ortzi Akizu-Gardoki ${ }^{1,2}$, Gorka Bueno ${ }^{3}$, Thomas Wiedmann ${ }^{4}$, \\ Jose Manuel Lopez-Guede ${ }^{5}$, Iñaki Arto ${ }^{6}$, Patxi Hernandez ${ }^{7}$, Daniel Moran ${ }^{8}$ \\ ${ }^{1}$ University of the Basque Country (UPV/EHU), Department of Graphic Design and Engineering Projects, \\ Nieves Cano 12, 01006 Vitoria-Gasteiz, Spain \\ ${ }^{2}$ University of the Basque Country (UPV/EHU), Hegoa Institute for International Cooperation and Development Studies, Avda. \\ Lehendakari Agirre, 81, 48015 Bilbao Spain \\ ${ }^{3}$ University of the Basque Country (UPV/EHU), Department of Electronics Technology, Bilbao, Spain \\ ${ }^{4}$ Sustainability Assessment Program, School of Civil and Environmental Engineering, UNSW Sydney, Australia \\ ${ }^{5}$ University of the Basque Country (UPV/EHU), Department of Engineering Systems and Aưomatics, Vitoria-Gasteiz, Spain \\ ${ }^{6}$ Basque Centre for Climate Change, Bilbao, Spain \\ ${ }^{7}$ Tecnalia Research \& Innovation, Azpeitia, $\mathrm{S}$ \\ ${ }^{8}$ Norwegian University of Science and Technology (NTNU), Department of Energy nd Pr cess Iechnology, Trondheim, Norway
}

Historically, the growth of energy consumption has fu-1led uman development, but this approach is no longer socially and environmentally sustainable. Recent analyses sugges that so he individual countries have responded to this issue successfully by decoupling Total Primary Energy Supply f $m$ ath $\eta$ an wopment increase. However, globalisation and international trade have

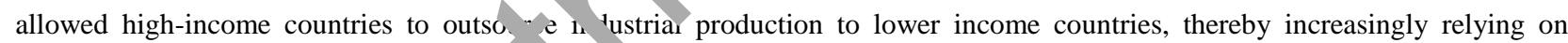
foreign energy use to satisfy their own $~ n s u$, tion of goods and services. Accounting for the import of embodied energy in goods and services, this study proposes an alterna ve estimation of the Decoupling Index based on the Total Primary Energy Footprint rather than Total Primary Ei To, Cupply...n analysis of 126 countries over the years 2000-2014 demonstrates that previous studies based on energy supply high. verestimated decoupling. Footprint-based results, on the other hand, show an overall decrease of the Decoupling Index for most , untries (93 out of 126). There is a reduction of the number of both absolutely decoupled countries (from 40 to 27) and relatively decoupled countries (from 29 to 17), and an increase of coupled countries (from 55 to 80). Furthermore, the study shows that decoupling is not a phenomenon characterising only high-income countries due to improvements in energy efficiency, but is also occurring in countries with low Human Development Index and low energy consumption. Finally, six exemplary countries have been identified, which were able to maintain a continuous decoupling trend. From these exemplary countries, lessons have been identified in order to boost the necessary global decoupling of energy consumption and achieved welfare.

Keywords: decoupling index; energy footprint; energy democracy; energy transitions; consumption based accounts; sustainable development goals

\section{Highlights:}

- Energy footprint accounts show an overall decrease of decoupling for most countries.

- Six exemplary countries show a maintained decoupling of HDI from energy requirement.

- Permanent or temporary decoupling has been detected in 89 countries.

- Both high and low-HDI countries can achieve temporary decoupling. 


$\begin{array}{ll}\text { Acronyms } & \\ \text { ADP } & \text { Absolute Decoupling Point } \\ \text { CBA } & \text { Consumption Base Accounts } \\ \text { DF } & \text { Driving Forcers } \\ \text { DI } & \text { Decoupling Index } \\ \text { EI } & \text { Education Index } \\ \text { EP } & \text { Environmental Pressure } \\ \text { GDP } & \text { Gross Domestic Product } \\ \text { GFC } & \text { Great Financial Crisis - Great Recession } \\ \text { GMRIO } & \text { Global Multi Regional Input-Output } \\ \text { HDI } & \text { Human Development Index } \\ \text { IEA } & \text { International Energy Agency } \\ \text { II } & \text { Income Index } \\ \text { LEI } & \text { Life Expectancy Index } \\ \text { MF } & \text { Material Footprint } \\ \text { PB } & \text { Planetary Boundaries } \\ \text { PBA } & \text { Production Based Accounts } \\ \text { TFC } & \text { Total Final Consumption } \\ \text { TPEF } & \text { Total Primary Energy Footprint } \\ \text { TPES } & \text { Total Primary Energy Supply } \\ \end{array}$

\section{Introduction}

In order to achieve a global sustai $a b^{1}-$ us energy resources, energy consumption needs to respect socially fair and environmentally viau P Planetary Boundaries (O’Neill et al., 2018). The introduction reviews the literature to establish re ru aired energy to achieve development and define sustainable energy boundaries. Within $\mathrm{t}^{\mathrm{r}}$. cont $\mathrm{t}$, he decoupling phenomenon has been observed, in which energy consumption can be red cf $\mathrm{W}$ While increasing countries development levels.

\subsection{Energy consumption requirements}

The correlation between the energy consumption and welfare of a country has been a well discussed topic. There is general agreement in the literature that a certain amount of energy consumption is fundamental to the economic progress and social development of a country (Wu and Chen, 2017). Nevertheless, there is still no consensus regarding the minimum thresholds of energy consumption needed to achieve acceptable living standards. Krugmann and Goldemberg (1983) found that between 11.5 and 15.7 MWh per capita per year was the cost of satisfying the basic human needs. Subsequently, an economic minimum requirement of 7.25 MWh per capita per year was identified (Grabl et al., 2004). Comparatively, Martínez and Ebenhack (2008) identified that $9.3 \mathrm{MWh}$ per capita per year $\left(\mathrm{MWh} \cdot \mathrm{cap}^{-1} \cdot \mathrm{yr}^{-1}\right)$ were necessary to maintain the HDI level above 0.7, and 33.7 MWh in order to uplift the HDI value above 0.9. With 2005 data, it was stated that an average consumption of $16.7 \mathrm{MWh} \cdot \mathrm{cap}^{-1} \cdot \mathrm{yr}^{-1}$ was enough to achieve a $0.8 \mathrm{HDI}$ value (Steinberger and Roberts, 2010). Subsequently, using the Life Expectancy parameter, Mazur (2011) detected that all 
nations consuming above $40 \mathrm{MWh} \cdot \mathrm{cap}^{-1} \cdot \mathrm{yr}^{-1}$ have life expectancies near 80 years. Similarly, in 2012 it was detected that energy consumption of above $43.8 \mathrm{MWh} \cdot \mathrm{cap}^{-1} \cdot \mathrm{yr}^{-1}$ does not necessarily lead to a higher Quality of Life Index (Pasten and Santamarina, 2012). Finally, Steckel et al. (2013) found that 27.8 MWh $\cdot \mathrm{cap}^{-1} \cdot \mathrm{yr}^{-1}$ could very likely maintain the HDI higher than 0.9 .

\subsection{Energy consumption boundaries}

In order to match human energy needs to available energy, current research attempts to understand how much energy is accessible worldwide as well as which the physical and sustainable Planetary Boundaries (PB) are (Rockström et al., 2009), in order to preserve the Earth System in a resilient and accommodating state (Steffen et al., 2015). The natural limits of global energy resources were recognised by the scientific community for the first time in the 1970s (Meadows et al., 1972). Currently, forecasting the peak-oil is a constant challenge for the scientific community (Pargman et al., 2017). Current fossil-fuel-based global energy consumption threshold needs to be lowered, since is has been defined as: environmentally unsustainable (Inman, 2008), (IPCC, 2015), (Gies, 2017), sociallv un. (Sovacool et al., 2016) (Eisenstein, 2017), and further economic losses and crises have en 1 rece ted (Hsiang et al., 2017) (Fouquet, 2017) (Inman, 2013).

In response to the knowledge of energy limitations, as well as an. empt to promote an equal opportunity to the access of energy for all citizens in the world, i. 1998 he Swiss Government promoted the "2000 Watt Society" (Stulz et al., 2011). The initiative had the ambitious target of reducing $60 \%$ of the Total Primary Energy Supply (TPES) from 41 to $17-2 \mathrm{~N} \cdot \mathrm{Vh} \cdot \mathrm{cap}^{-1} \cdot \mathrm{yr}^{-1}$ (Heeren et al., 2012). However, 18 years later, in 2015, the TPES of the countrv v s st $134.46 \mathrm{MWh} \cdot \mathrm{cap}^{-1} \cdot \mathrm{yr}^{-1}$ (International Energy Agency, 2015). But this figure does not inch le th energy consumed in other countries embodied in imported products and services, which has bec. gro ving in recent decades (Arto et al., 2016).

The shift towards renewable nerg. sources has been stated to be environmentally indispensable (IPCC, 2015) and even benefi tar economic or social terms globally (Jacobson and Delucchi, 2011) (WWF, 2011) (Jacobson et al., 2 15) (Teske et al., 2015) (García-Olivares, 2016) and nationally (Kucukvar et al., 2017), as demonstrated by using the Triple Bottom Line methodology (Slaper and Hall, 2011). According to optimistic studies, a $100 \%$ renewable energy supply for 139 countries could be possible within 2050, while actually maintaining the global energy consumption of 2012 (Jacobson et al., 2017). In this respect, even if all the countries in the world could be able to maintain 2012 consumption levels within renewable generation (13,267,620 ktoe, International Energy Agency, IEA), maintaining human population in 2012 levels (7100 millions) each individual would have the equal right of consuming a Total Primary Energy Footprint of $21.9 \mathrm{MWh} \cdot \mathrm{cap}^{-1} \cdot \mathrm{yr}^{-1}$ of fully renewable energy. Nevertheless, limits for renewable energies have been discovered. For example, taking into account the land usage in the case for the solar resource, has concluded that a global transition to domestically produced renewable solar energy will be physically unfeasible to maintain current energy consumption levels (Capellán-Pérez et al., 2017). Other research has considered a strong limit in renewable energy penetration; in an optimistic scenario, the total installed capacity of renewables is forecasted to saturate at around $1.8 \mathrm{TW}$ in 2030 (Hansen et al., 2017) and maximum global production capacities of around 145,000 TWh in 2050 (Capellán-Pérez et al., 2014). 
Being aware of these limits, Cullen et al. (2011) analysed the capacity of reduction of TPES through savings and efficient management and concluded that a $73 \%$ reduction would be feasible. A global energy consumption reduction from $475 \mathrm{EJ} \cdot \mathrm{yr}^{-1}$ to $129 \mathrm{EJ} \cdot \mathrm{yr}^{-1}$ (based on the 2005 data) was identified as feasible, reducing energy use from buildings, transport and industry (Cullen et al., 2011). This baseline would give each citizen the equal right to consume of $4.7 \mathrm{MWh} \cdot \mathrm{cap}^{-1} \cdot \mathrm{yr}^{-1}$. Nevertheless this reduction capacity has been contrasted based on the difficulty of reducing current energy consumption levels; especially due to the strong correlation between energy consumption and economic growth (Sorrell, 2015).

Lastly, due to the limitation of the Planetary Boundaries, has been found that generally the current resource consumption level is 2 to 6 times the sustainable level one (O'Neill et al., 2018). Thus, taking into account the present global energy consumption (13,647,367 ktoe in 2015, IEA) and assuming the positive condition that population figures will be maintained (7,355 millions in 2015, World Bank), energy consumption should be reduced to between 3.6 and $10.8 \mathrm{MWh} \cdot \mathrm{cap}^{-1} \cdot \mathrm{yr}^{-1}$.

\subsection{Decoupling}

Being aware of the limited availability of energy (renewabl or ss, the decoupling between energy consumption (and its impacts) and the achieved welf re has bu defined as a "key issue" to reach the Sustainable Development Goals (SDGs) (UNEP, 2 11), (I NEP, 2014). This issue establishes how humanity should be able to maintain current life standards in developed countries and promote development in low-income countries witho fto ting the environmental bio-capacity of the Earth. To accomplish the decoupling challenge, tech logi al innovations (eco-efficiency and system innovations) have been seen as the main leverage. (UN ' D, 2011), (UNEP, 2014). As a secondary aspect, the need to encourage change in consumption atte.ns, to reduce the consumption of resources while achieving improvements in quality of lis has een identified as an influential factor (UNEP, 2014). These objectives are aligned with "Goal 7" CDU (UN, 2015) where the sustainable energy availability is recognised as a right for all individuals, Goal 10" of SDG, where equality between countries is recognised, and finally "Goal 12" where sustainable consumption ways are claimed.

Since 1970, the relation between consumed energy and gained GNP or GDP has been widely studied and has assessed the possibility of decoupling (Bullard and Foster, 1976), (Meadows et al., 1972), (Nilsson, 1993). In 2002, an extensive study was developed by the Organisation for Economic Co-operation and Development (OECD, 2002), where indicators to measure the Environmental Pressure (EP) from specific Driving Forcers (DF) were classified, and the variation ratio between EP and DF during a certain period was defined as the Decoupling Factor (DF). Mielnik and Goldemberg (2002) analysed the decoupling phenomena in 20 developing countries, concluding that technology improvements due to foreign investments could promote a decoupling. Decoupling was also analysed in the transportation sector, between consumed energy and provoked emissions (Tapio, 2005). Diakoulaki and Mandaraka (2007) analysed the decoupling between emissions and industrial growth within the $14 \mathrm{EU}$ countries, finding that a considerable effort has been done for decoupling. Decoupling between environmental impacts (measured in $\mathrm{CO}_{2} \mathrm{eq}$ emissions) and GDP has also been analysed in Brazil (de Freitas and Kaneko, 2011), and between 
consumed energy and GDP in China (Zhang et al., 2015). Both studies concluded that technology played an important role in decoupling in Brazil, reducing the carbon intensity of the generation mix, and in China, increasing the energy efficiency (energy intensified effect). In China was founded that decoupling was also a result of the rapid economic growth of the country (Wang, 2011).

A more recent study, that analysed the decoupling phenomenon in eight countries, concluded that decoupling, is more present and constant in developed countries (Wu et al., 2018). Wu et al. (2018) used a specific Decoupling Index (DI) of Impact-GDP-Technology (IGT) in different countries within GDP and TPES, where this decoupling is clearly observed in developed countries such as the UK, France, and USA. In the study, absolute decoupling and relative decoupling terms were used to clearly distinguish the achievements of different countries.

Nevertheless, relating the decoupling phenomenon to technological advancements of the developed countries, has already been considered for re-evaluation (Moreau and Vuille, 2018). When integrating footprint accounting in resource consumption measurements, it was found hat the decoupling between economic achievements and environmental impacts was "smaller ala repo ed or even non-existent" (Wiedmann et al., 2015), due to exporting production chains to other our ries. Moreau and Vuille (2018) states that decoupling is still under discussion due to the virtue decoupling" concept. The "virtual decoupling" occurs when a developed country argues to redur energy consumption, while in reality has only exported the industrial production chains to other le do eloped countries (Moreau and Vuille, 2018), thus national energy measurements are not able $\mathfrak{k}$ detect this consumptions. As a result, even if decoupling has been defined as a necessary factor to ach eve Istuinable goals, it is not clear which countries and when

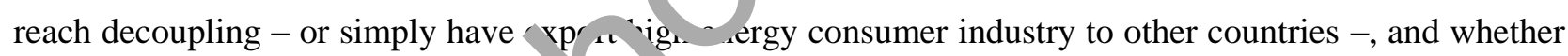
there is an impetus to attain it.

\subsection{Accounting for toc nrimary energy consumption}

In order to determine de oupling, energy consumed by a country may be measured in different ways that affect the results. The Total Primary Energy Supply of a country (TPES) and the Total Final Consumption (TFC) have been the most popular indicators when measuring energy consumption, both defined by the (International Energy Agency, 2015). TPES is the sum of TFC and the losses of the energy transformation and distribution sectors (Goldemberg and Siqueira Prado, 2011). However, TPES and TFC are both Production Based Accounts (PBA), where energy consumption is measured within the boundaries of a country (Peters, 2008). In present day, the massive outsourcing of industrial production chains and services (especially from high-income countries to low-income ones), causes the total energy consumption of highincome countries appears to be smaller, since part of it is outsourced and accounted for in other countries (Arto et al., 2016).

To address this occurrence, scientists have used Consumption Base Accounting (CBA). CBA was initially used for Carbon Footprint measurement (Munksgaard and Pedersen, 2001), (Peters, 2008), (Peters and Hertwich, 2008), (Kanemoto et al., 2012), (Barrett et al., 2013) using the Global Multi Regional InputOutput (GMRIO) methodology (Wiedmann and Lenzen, 2018). Footprint accounting has become a well- 
established method to trace the total resource needs and environmental impacts of a country's consumption (Wiedmann et al., 2007), (Galli et al., 2012), (Hoekstra and Wiedmann, 2014), (Wiedmann et al., 2015).

Using the same GMRIO methodology, the "Energy Footprint" concept was developed (Arto et al., 2016). This considers the energy embodied in imported goods and services that is consumed in other countries, and is defined as Total Primary Energy Footprint (TPEF). TPEF allows relocating the energy accounts according to the final consumers.

It needs to be clarified that the concept of Energy Footprint has been used either for specific industrial processes (processing with the LCA methodology) or to calculate whole countries' energy footprints (such as in this research, using the GMRIO methodology). Generally, when the term Energy Footprint is used to calculate the external energy use of specific industrial manufacturing or resource extraction processes, the concept Cumulative Energy Demand (CED) is used and Life Cycle Assessment (LCA) methodology is more frequent (Röhrlich et al., 2000), (Huijbregts et al., 2010), (Puig et al,, 2013). Nevertheless, in this research, Energy Footprint specifically refers to the CBA energy consump ion of a determinate whole country.

Several studies have been developed in this field, taking into accoun. dif' OECD, Eora and EXIOBASE) as well as different colmies Cher ana Lin, 2008), (Wiedmann, 2009), (Mativenga and Rajemi, 2011), (Chen and Chen, 2013, (Hein nen and Junnila, 2014), (Arto et al., 2016), (Lan et al., 2016). The latest research in the energy field insed comparing the accuracy of results when calculating the energy footprint (Owen et al., 017), (Min and Rao, 2017); forecasted future energy scenarios (Kucukvar et al., 2017), (Kalte eggt e. al., 2017); as well as computed energy footprint calculations based in single years ( $\mathrm{v} u \mathrm{u}$. 2017), (Chen and $\mathrm{Wu}, 2017)$, (Rocco et al., 2018), (Chen et al., 2018), (Wood et al., 2018), $\nabla$ naı. et al., 2018).

Despite these advancements, the dec pling phenomenon between the TPEF and subsequent achieved welfare has not been ${ }^{-1}$ dressec in broad way through -analysing contemporaneously several countrieswith the use of a De o'pling Index and Energy Footprint accounts. Given the precedent "virtual decoupling" detected in S yitzerland (Moreau and Vuille, 2018), the possibility of studying decoupling in several countries within a footprint account perspective is especially relevant.

\subsection{Study aims}

The objective of this study is to analyse unsolved decoupling phenomena between Total Primary Energy Footprint (TPEF) and achieved welfare (measured with HDI) among 126 countries from 2000 to 2014. The presence of the decoupling effect in developed and non-developed countries has been studied, in an attempt to define any link between the level of development in a country and the achievement of decoupling.

For this purpose, the TPEF of 126 countries has been calculated using CBA during 2000 and 2014. With these data, the Decoupling Index (DI) between consumed energy and achieved HDI (defined in Methodology section) has been calculated, analysing the difference between TPES and TPEF results. Secondly, TPEF based DI versus gained HDI has been analysed and countries have been classified in four decoupling types. At this stage, exemplary countries have been identified dividing the Decoupling Index in four year gaps: 2000-2004, 2004-2008, 2008-2012 and 2012-2014, where maintained decoupling has been 
achieved. Thirdly, country-based, time series have been developed in order to more accurately observe the decoupling trends of exemplary countries. Lastly, temporary decoupled countries have also been detected in order to understand which countries could achieve future absolute decoupling trends.

Section 2 of this paper illustrates the Global Multi-Region Input-Output method used. Section 3 breaks down results divided in the above defined four parts and in Section 4, the results are discussed. Finally, Section 5 provides recommendations and implications for improved policy making.

\section{Methods and data}

\subsection{GMRIO calculation}

Global Multi Regional Input-Output (GMRIO) methodology has been used to calculate the Total Primary Energy Footprint (TPEF) from the initial Total Primary Energy Suppl (TPES) obtained from the International Energy Agency (IEA). This has been accomplished using th $x_{1}$ industry sector based Eora database economic information for 189 countries (Lenzen et al., ? 12). $1 \mathrm{mc}$ e detailed version of this database, with 15,909 sectors, is available (Lenzen et al., 2013) out, in - the original energy data from the IEA matches better with 26-sector version of Eora, the ormer ha he $\mathrm{n}$ considered more appropriate for the purpose of this research. It must be clarified that the $\mathrm{Ec}$ a $26 \mathrm{da}$ abase estimates the economic sectorial data of certain industries in some countries, thus when ssing these data to calculate the TPEF of a country, the errors already reported in economic matrixes wilt he reflected in the calculated footprints. According to Moran and Wood (2014), after performin a se sitivity analysis within a harmonised carbon footprint satellite account, differences between ${ }^{\top}$ ora, VIOD, EXIOBASE and GTAP databases are smaller than 10\% in most major economies. Reduciris unce ainty in MRIO analysis has been identified as relevant work for the future standardization of mults Rodrigues et al., 2018), but it is out of the scope of this paper. 


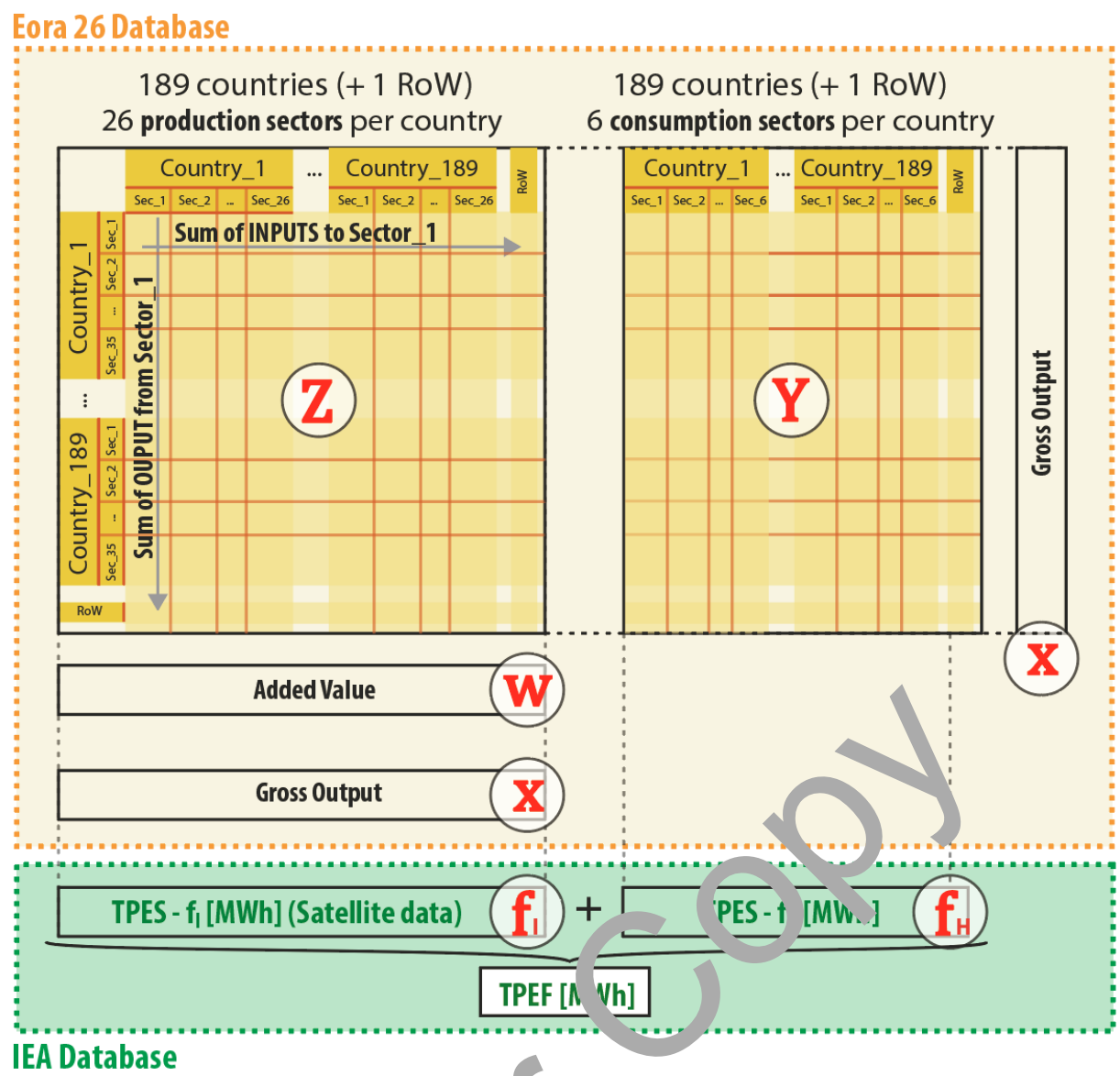

Figure 1: Global Multi-Regional Input-Output (GM ) st. 'cture with the Eora 26-sector database (orange) and TPES data from IEA (green). The final block in the original ve sion o, Eora reports 6 categories of final demand for each country. For the sake of simplicity, for each one, we have aggremea he 6 ategories by country into one. Adapted from Miller and Blair (2009).

A standard, environmentally exteria d, a nand-driven input-output model has been used (see Figure 1) to calculate the TPEF of countrins (O n et al., 2017), (Oita et al., 2016), (Lenzen et al., 2004), (Wiedmann et al., 2007). In order to Pla IEA - PES energy data with the Eora 26 economic database, a row vector of satellite data of energy , nsumption for each industrial sector by country was created $\left(\mathbf{f}_{\mathrm{I}}\right)$ following the criteria indicated in Supplementary Table 1. The TPES is the sum of energy consumption by industries $\left(\mathbf{f}_{\mathrm{l}}\right.$, a row vector with information on the energy use of 189 countries and 26 sectors) and the direct use of energy per household ( $f_{H}$, a row vector with information on energy use per household in 189 countries). This method, also known as the Leontief equation, follows the sequence of equations below. Firstly, the energy consumption coefficient per unit of industrial output (c vector) has been calculated, where diag stands for the diagonalization of a vector, as:

$$
\mathbf{c}=\mathbf{f}_{\mathbf{I}} \cdot(\operatorname{diag}(\mathbf{x}))^{-\mathbf{1}}
$$

The technical coefficients matrix (A) has been calculated, and from this in turn we arrive at the Leontief Inverse (L): 


$$
\begin{gathered}
\mathbf{A}=\mathbf{Z}(\operatorname{diag}(\mathbf{x}))^{-\mathbf{1}} \\
\mathbf{L} \equiv(\mathbf{I}-\mathbf{A})^{-\mathbf{1}}
\end{gathered}
$$

Next, the total (i.e. a scalar) industrial energy embodied in the products and services demanded by country $r$ $\left(\mathrm{g}_{\mathrm{I}}^{\mathrm{r}}\right)$ is obtained using the standard demand-driven IO model:

$$
g_{I}^{r}=\mathbf{c L y} \mathbf{T O T}
$$

Where $\mathbf{y}_{\text {TOт }}^{\mathbf{r}}$ is a column vector $(4915 \times 1)$ representing the total final demand of goods and services by country $r$.

Finally, we obtain the total TPEF of country $r$ as the sum of the industrial energy embodied in the products and services $\left(\mathrm{g}_{\mathrm{I}}^{\mathrm{r}}\right)$ and the energy consumed directly by final users $\left(\mathrm{g}_{\mathrm{H}}^{\mathrm{r}}\right)$.

$$
g^{r}=g_{I}^{r}+g_{H}^{r}
$$

In this study, due to the insufficiency of the energy cor umptic country-based satellite data, and the extant difficulties of cross-referencing the results of MRIO ana. cis s th HDI data, we have however obtained the results for 126 countries out of the total 189 Eora atabase countries.

\subsection{Human Development Index}

The Human Development Index has en th selected indicator to compare the consumed energy with the achieved welfare of a country; as is a counts for the economic advantages but also improvements in human well-being (Sen, 1992 Dat has been derived from UNDP (UNDP, 2015) and has been processed in order to obtain ave $g 0$-ands, which have been used to validate the final conclusions of the project. HDI, shown in Equation , is the geometric mean of Income Index (II), Life Expectancy Index (LEI) and Education Index (EI), based in the aggregation of economic, health and education level of a country (UNDP, 2017).

$$
H D I=\sqrt[3]{L E I \times I I \times E I}
$$

\subsection{Decoupling Index}

The decoupling phenomena, has been most frequently graphically observed (Wiedmann et al., 2015), (Steinberger and Roberts, 2010). Nevertheless, the Decoupling Index (DI) (Wang, 2011), (Wu et al., 2018), is a crucial parameter that enables to compare the achievements of a single country over time, or to compare different countries with each other. The DI allows understanding how countries are reducing environmental burdens (in this case energy consumption) while increasing their development status. The difference between relative decoupling and absolute decoupling is especially important since the latter implies an energy reduction in absolute terms. The $\mathrm{DI}_{\mathrm{GDP}}$ has been a development from the well known 
$I=P A T$ formula (Wu et al., 2018), obtaining the final Equation 7; where $g$ represents the average increase of GDP, and $t$ represents the average decline rate of energy consumption per unit of GDP between the selected years (Supplementary Note 1 shows how the left side of Equation 7 is equal to the right side).

$$
\begin{gathered}
D I_{G D P}=\frac{t}{g} \times(1+g)=\frac{\Delta G D P(\%)-\Delta T P E S(\%)}{\Delta G D P(\%)} \\
D I=\operatorname{ARCTAN}\left(\frac{\Delta \operatorname{HDI}(\%)}{\Delta\left(\frac{\text { EnergyConsumption }}{P}\right)(\%)}\right)
\end{gathered}
$$

In this study, Equation 7 has been used as a reference to create Equation 8, replacing GDP by HDI and adding the population variable $\mathrm{P}$, the $\mathrm{DI}_{\mathrm{HDI}}$ (referenced as $\mathrm{DI}$ ) is achieved. The results have been calculated in degrees due to the differences between GDP and HDI. The use of degres a lows having a clearer visual range, since the HDI values have the maximum value of 1.0 wher cas FDP ( oes not present a specific maximum. Equation 8 shows how Figure 2 has been created, th cro of HDI and energy consumption have been included in percentage.
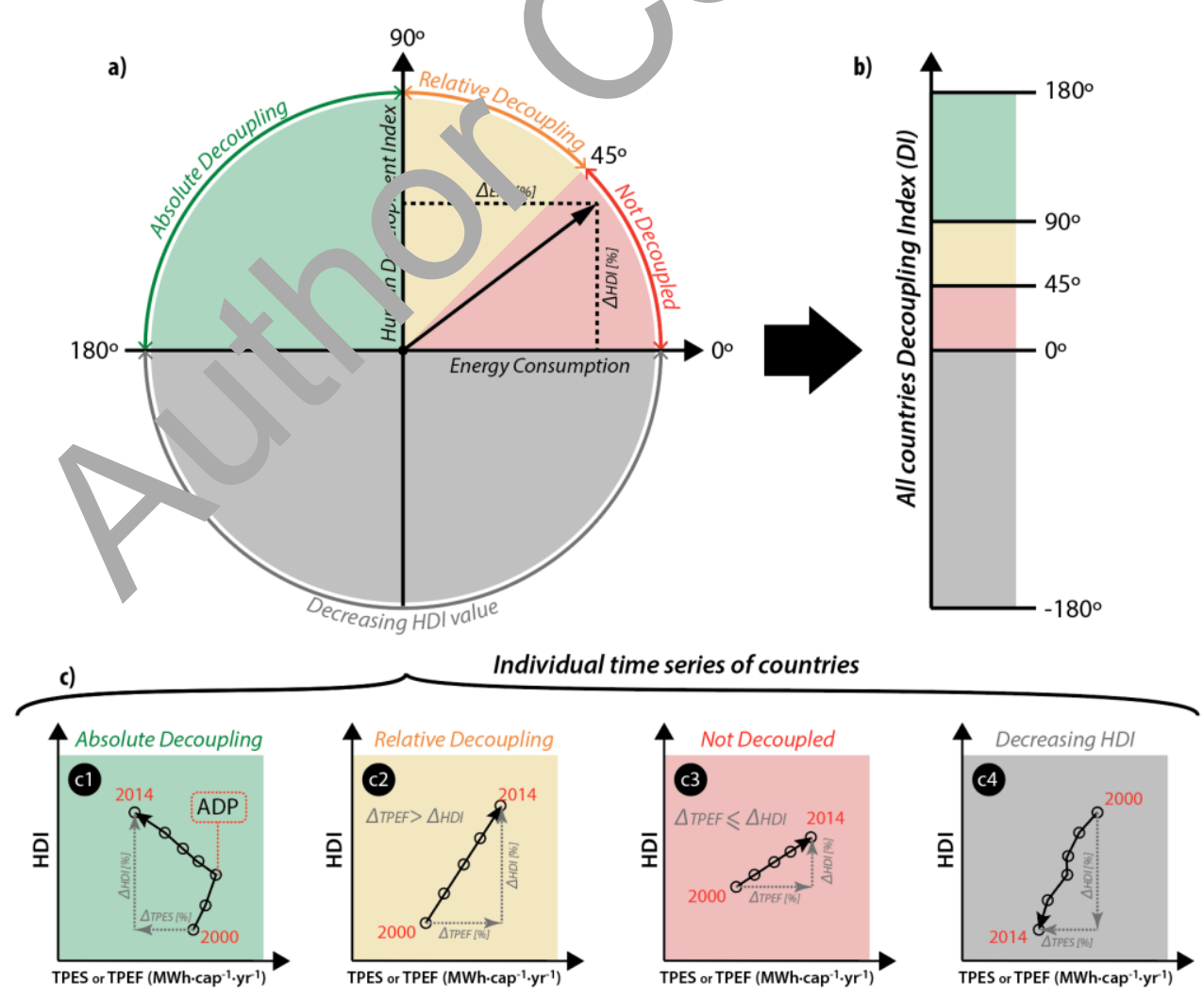

Figure 2: Decoupling Index indicator between HDI and energy consumption.

It must be clarified that Equation 8 results range, due to the use of ARCTAN, was originally from -90 to 90, since the formula itself is not capable of distinguishing whether the variation of HDI or energy consumption is positive or negative on their own. Thus, in order to properly identify the negative or 
positive symbols, Matlab has been used, generating a results range from -180 to 180 degrees (see Supplementary Note 2). Figure 2 (a) shows how the results have been identified in quadrants (Zhang et al., 2017), and Figure 2 (b) shows how these quadrants have been converted into a linear visualization mode; this allows the comparison of the results of DI with a single vertical arrow according to TPES and TPEF data as shown later in Figure 3. Four different trends have been identified among countries shown in Figure 2 (c), according to the Decoupling Index methodology:

c1. Absolutely decoupled countries $\left(90\right.$ to $\left.\mathbf{1 8 0}^{\circ}\right)$. Those who are reducing their TPES (or TPEF) and increasing their HDI. Figure 2(a) shows how the Absolute Decoupling Point (ADP) could be graphically identified in the annual series. ADP corresponds to the point after which energy consumption started reducing while still HDI is still increasing. (e.g. FRA: HDI $+5 \%$, TPEF $-10 \%$, DI $\left.153^{\circ}\right)$

c2. Relatively decoupled countries $\left(45\right.$ to $\left.9^{\circ}\right)$. Those countries that need to increase their energy consumption to increase the HDI value, but the percentage of eneroy $c$ nsumption increase is lower than the increased HDI percentage. (e.g. MOZ: HDI $+39 \%$, TP $7 \%$, $\mathbf{L}\left(80^{\circ}\right.$ )

c3. Not decoupled countries $\left(0\right.$ to $\mathbf{4 5}^{\circ}$ ). Countries that need to 1 cre se their energy consumption at least in the same or greater percentage that the incmse $f$ the chived HDI value. (e.g. NOR: HDI $+3 \%, \mathrm{TPEF}+11 \%$, DI $\left.17^{\circ}\right)$

c4. Reduction of HDI $\left(0^{\circ}\right.$ to $\left.-\mathbf{- 1 8 0}^{\circ}\right)$. In this case 1 ifferent subsections could be distinguished. Firstly, there is a scenario where ent ry consumption increases, and secondly one where

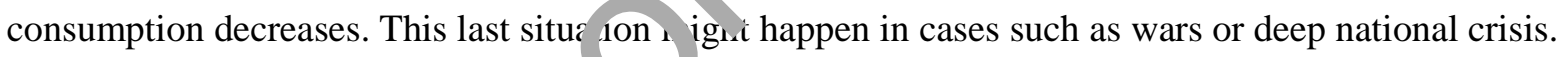
Eventually, in high-develope $c$ momentary soft decrease of HDI could be justified in order to achieve planned en y ductions. (e.g. SYR: HDI -6\%, TPEF -30\%, DI -168\%)

\section{Results}

Results have been divide into four subsections matching the specific aims of the study (Section 1.5).

\subsection{Decoupling Index as measured by TPES and TPEF}

The index has been calculated according to the methodology introduced in Section 2.3. Figure 3 shows that the Decoupling Index (DI) changes significantly in many countries when considering TPES or TPEF data. There is a general trend of decreasing the DI in most of the countries (93 countries out of 126 decrease their DI while 33 increase it). The number of absolutely decoupled countries have been reduced from 40 to 27 , the number of relatively decoupled countries have been reduced from 29 to 17 and instead the amount of coupled countries have increase from 55 to 80 using TPEF account.

This general trend to reduce the DI of countries when using TPEF accounts occurs due to an energy consumption increase in percentage in comparison with TPES accounts, while maintaining the same HDI gain. In high-income countries, even though the imported embodied energy has been generally slightly reduced since the Global Financial Crisis (GFC, or Great Recession) (Mazumder, 2018), is still higher than in 2000; and in low-income countries imported embodied energy has been slowly growing since 2000. 
Thus, during the analysed time period, low-income countries and high-income countries in general have a worse Decoupling Index with TPEF accounts. Therefore, even if the sum of the TPES and TPEF of all countries is equal, same quantity of energy consumption is extracted from exporter countries to be relocated in importer ones; in the Decoupling Index, a there is not a balance between countries that increased and decreased the DI value when using TPEF accounts (Supplementary Figure 1).

Countries that have an absolute decoupling within TPES, such as AUS, CAN, KWT, NLD, NOR, ROU, SVK, CHE and TJK, are coupled when using TPEF data; meaning that their consumption implies larger levels of energy than their production for the same level of HDI. Similarly, some countries that are shown to have a relative decoupling with TPES values, appear to be coupled under TPEF accounts, such as AZE, BWA, HRV, GHA, KEN, NPL, NZL, PRY, POL, MDA, SRB and YEM. Other countries, which are shown to be in absolute decoupling situation with TPES, are only relatively decoupled according to TPEF data, such as: DOM, FIN, LUX and UKR.

On the other hand, a total of 33 out of 126 countries improved their DI valut when using TPEF accounts. The highest variations occurred in 3 countries; BLR, which seem $n$ be a upled according to TPES calculations, is absolutely decoupled; and MEX and MLT, whish a re atively decoupled according to TPES measurements, are absolutely decoupled in TPEF trms.

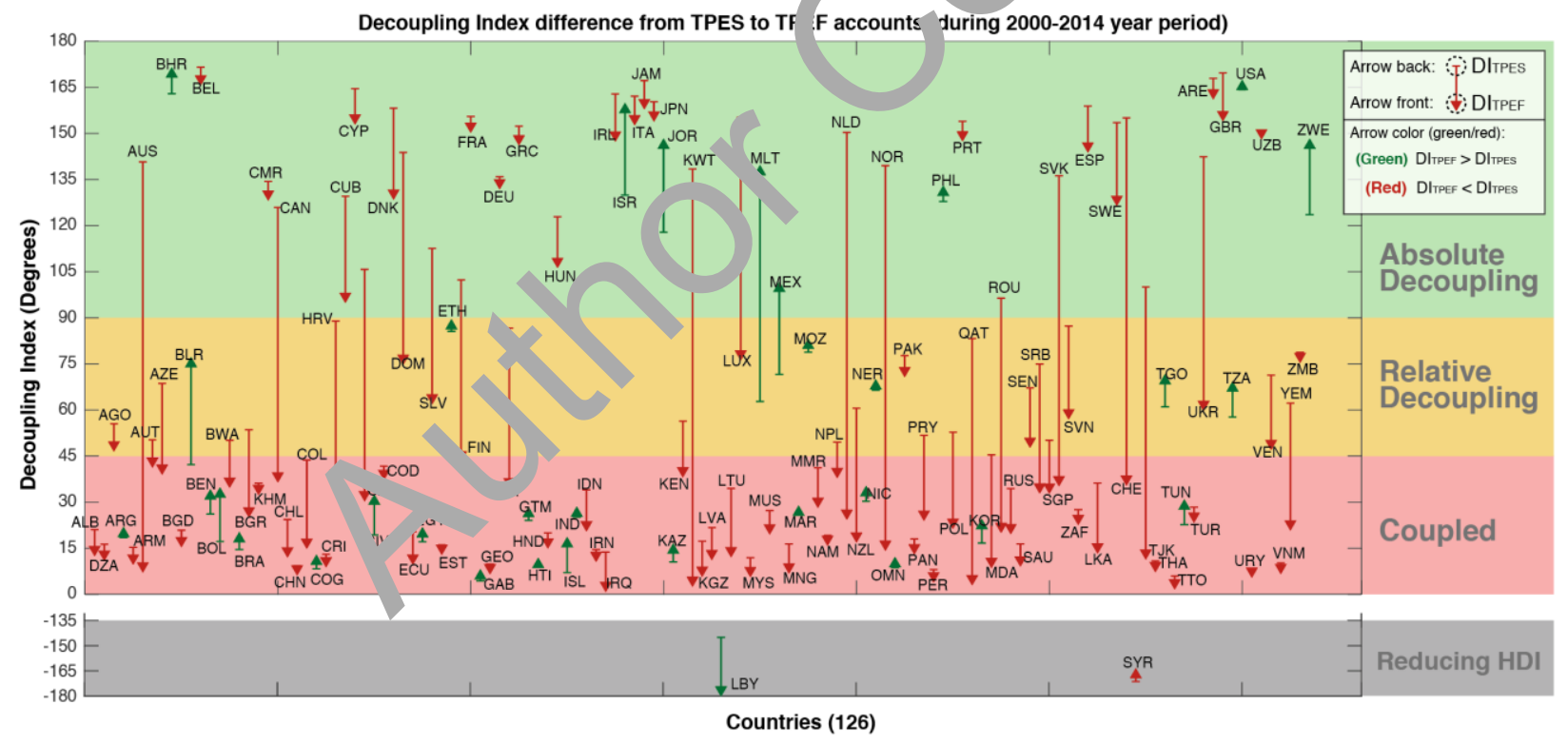

Figure 3: The arrows start in the $D I_{T P E S}$ and end in the $D I_{T P E F}$, and both are calculated using consumption based accounts (CBA), during the 2000-2014 period. The red arrows show how in 93 countries (from the analysed 126 ones) TPEF reports a smaller DI than that offered by TPES data, and the green arrows show how in 33 countries the TPEF identifies a greater DI than that detected by TPES data.

\subsection{TPEF based Decoupling Index versus HDI}

Figure 4 shows the relation between the development level (in terms of HDI) and the achieved DI (based on TPEF accounts) in 2000-2014 split into four periods: 2000-2004, 2004-2008, 2008-2012, and 20122014. It can be seen that every period follows a very different pattern.

Noticeably, although decoupling is generally less present when TPEF data is used, successive years indicate increasing numbers of countries that are reaching the absolute decoupling (Figure 4 and Figure 5). 
Nevertheless, some high-HDI countries, that have been absolutely decoupled during the first three periods, are not anymore decoupled during the last period (USA, DEU, DNK) (Figure 5).

Intriguingly, it is remarkable that countries with extremely low HDI, have achieved temporary in periods 2 and 3 (NER, YEM, ZWE, MOZ) (Figure 4). However, there are fewer less-developed countries that are absolutely decoupled during the last period or are able to maintain the decoupled trend long term.
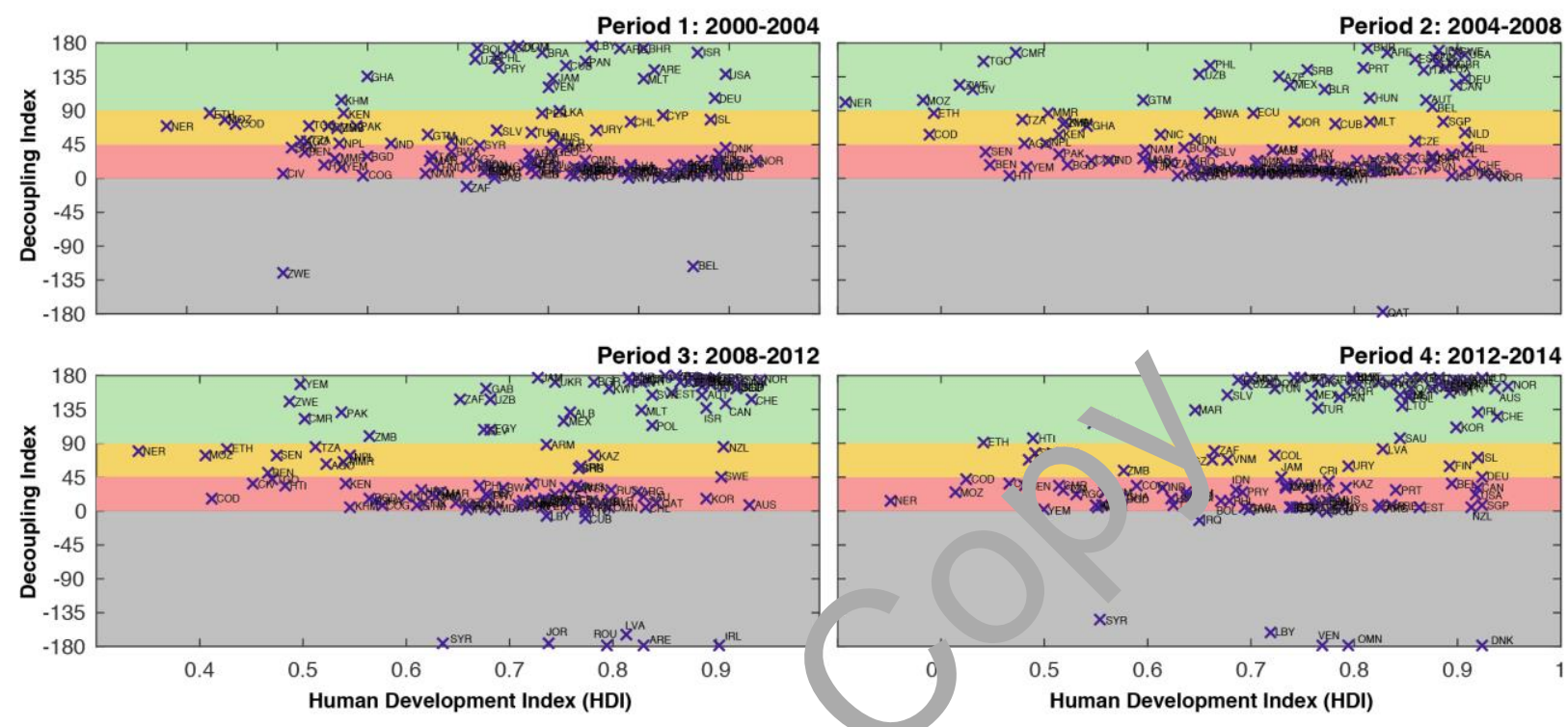

Figure 4: In this figure, $D I_{T P E F}$ and its relation with $H D I$ ave been analysed. The main goal of this figure is to understand the general trends of countries, shown by the "dark" areas of " charts. As can be seen, in Period 1 the only "dark" area is in the dependent (red) zone, while in Period 3 and Per 'd 4, .w dark" areas appear in the absolutely decoupled (green) zone.

Figure 5 has been created by zoomin $\iota_{c}$ into igure 4 in order to better understand the countries that could serve as a reference for "best practic." co.ntries, with an HDI value between 0.8 and 1.0 and a Decoupling Index between $90^{\circ}$ and $180^{\circ}$, r anife ting an absolute decoupling. 

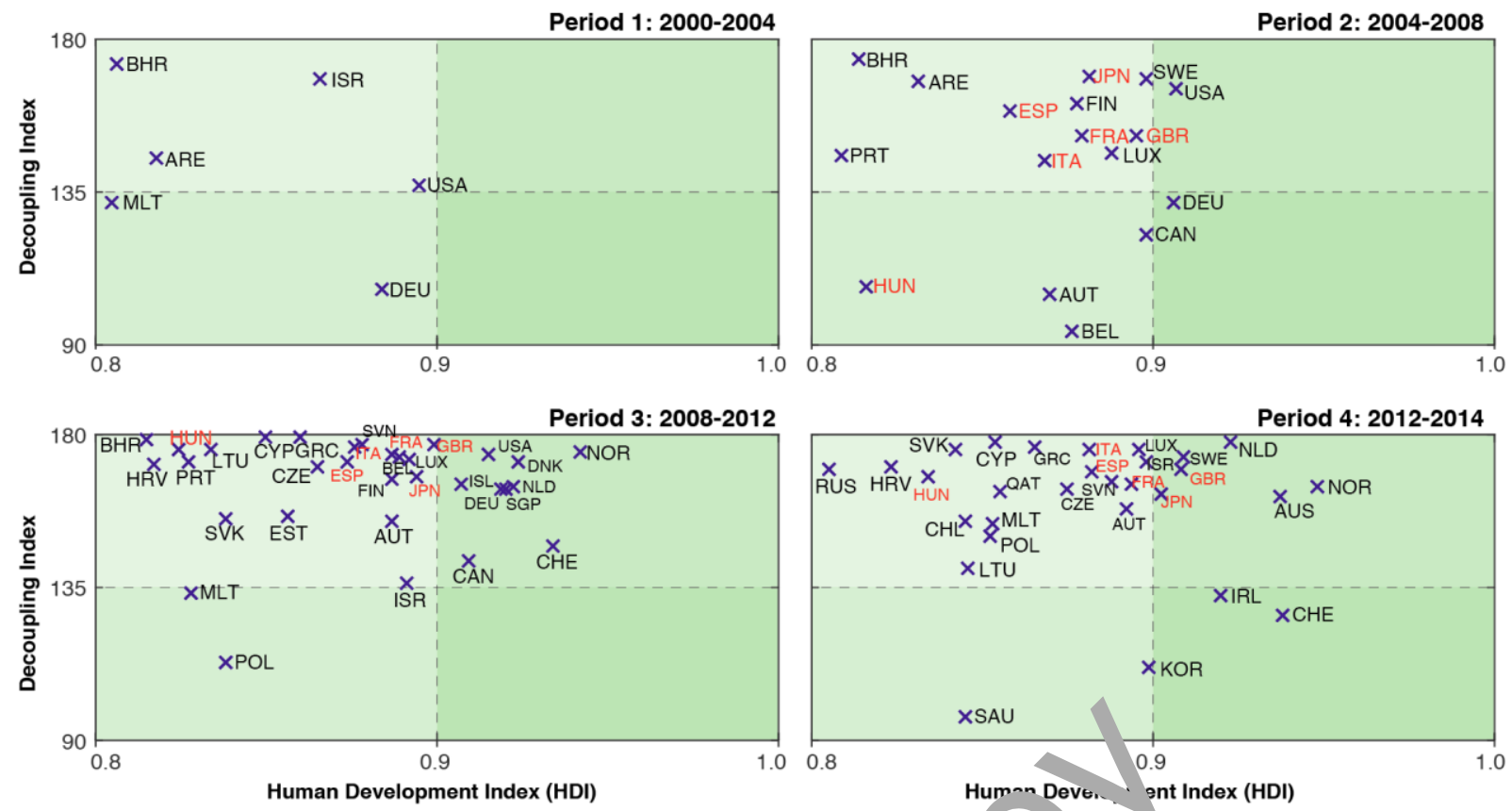

Figure 5: DI and HDI relation according TPEF accounts, during the four differen, erior: Exemplary countries (red) have been identified when at least in 3 periods have been able to ma itain $n$ a. volute decoupling trend.

Figure 5 shows that there is not a single country with a ntained absolute decoupling since 2000, and only 6 countries from the 126 analysed have an $\$$ DI above 0.8 and are manifesting a continuous absolute decoupling since 2004 (and also in average rom 200 to 2014): ESP, ITA, HUN, GBR, JPN and FRA. It could be understood that these co n atu uxemplary countries, which are achieving a maintained reduction of their energy consump in, hile maintaining a gain in HDI.

\subsection{Time series performa ces}

Time series were deve, per ar each of the 126 countries from year 2000 to 2014, and those for the six exemplary countries dete ted in the previous subsection have been shown in Figure 6, in order to better understand their dynamics. Has been found that, firstly, exemplary countries present more gradual and stable energy reductions during recent years, which were achieved in two ways: reducing energy consumption inside the country (observed from TPES curve) and reducing embodied energy consumption in goods and services imported from other countries (observed from TPEF curve), while increasing HDI. Hungary, Italy and Spain are the countries that have reached the major reductions in their TPEF values, with $29 \%, 30 \%$ and $33 \%$, respectively.

Secondly, all of the exemplary countries have been affected by the GFC increasing the reduction value of the TPEF from previous years. Nevertheless, all of them have been able to maintain the HDI increase tendency. This means that the crisis phenomena could be seen as an opportunity to reach reduction goals, rather than a risk, if it is properly managed (Schneider et al., 2010).

Additionally, a large difference in consumption is observed when Absolute Decoupling Point (ADP) was reached, meaning that each country could find its own strategy in order to improve their current consumption levels (Figure6). France, Japan and the United Kingdom present the highest ADP value, with 
60 to $65 \mathrm{MWh} \cdot \mathrm{cap}^{-1} \cdot \mathrm{yr}^{-1}$, and Hungary the lowest, with $36 \mathrm{MWh} \cdot \mathrm{cap}^{-1} \cdot \mathrm{yr}^{-1}$. Spain and Italy found the ADP at $48 \mathrm{MWh} \cdot \mathrm{cap}^{-1} \cdot \mathrm{yr}^{-1}$.

Finally, a critical observation was made that all of the exemplary countries have a higher TPEF than TPES, meaning that all of them are net importers of energy embodied in goods and services. This means that achieving a decoupling could be harder for net embodied energy exporter countries (such as China or India). It has been observed that generally only $14.2 \%$ of the absolutely decoupled countries are net embodied energy exporters, whereas from the relatively decoupled or coupled countries, net embodied energy exporters make up $41.2 \%$ and $41.3 \%$ respectively (Supplementary Table 2 ). This has been measured by comparing the obtained $\mathrm{DI}_{\mathrm{TPEF}}$ and the corresponding Hidden Energy Flow (HEF, HEF = TPES/TPEF 1, (Akizu et al., 2017) (Akizu et al., 2018)) of each country (Supplementary Table 2).
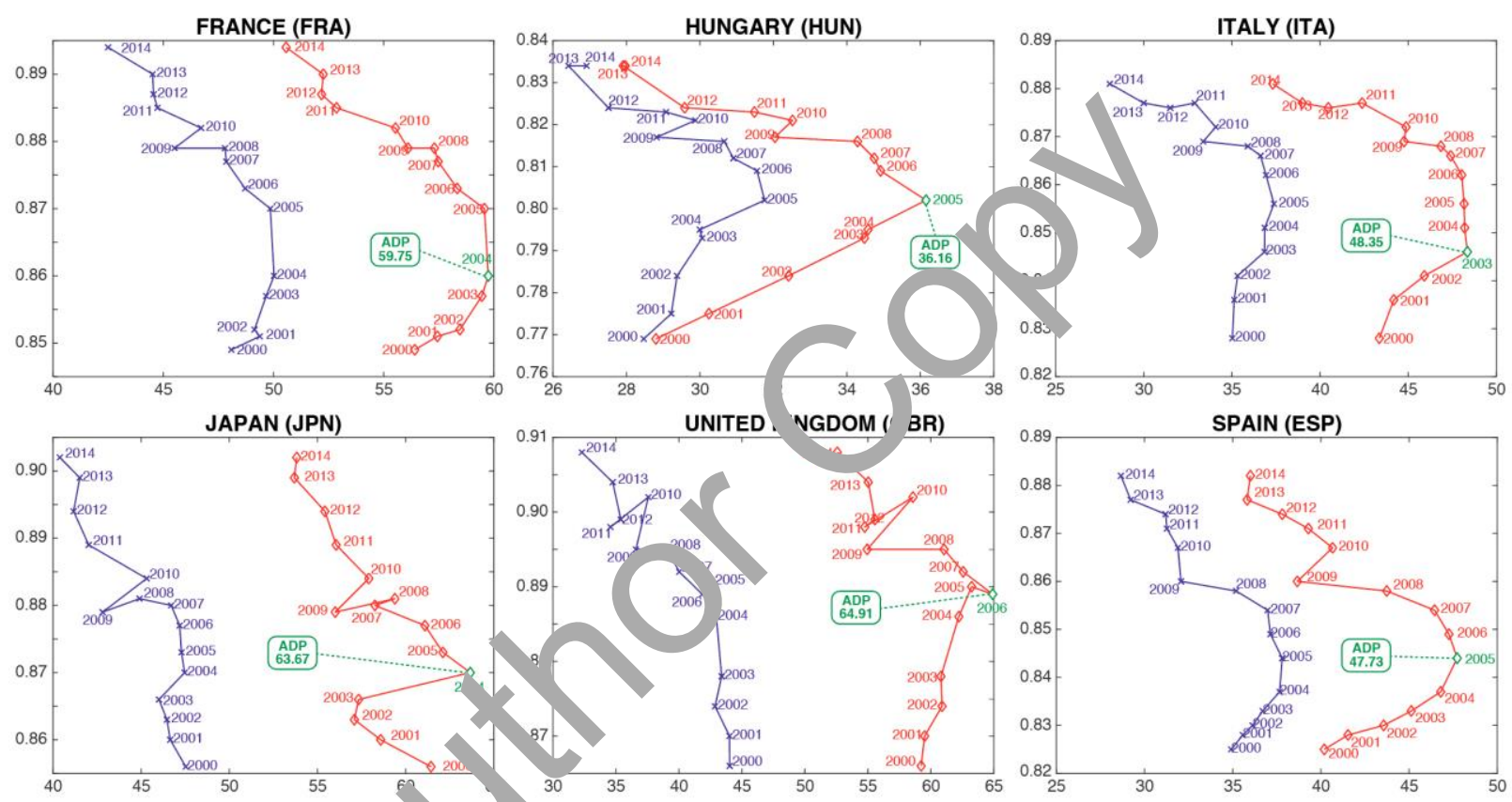

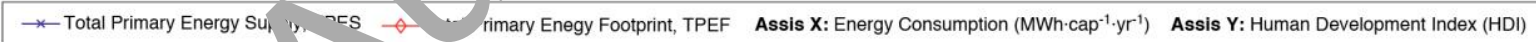

Figure 6: The consumed TPL S and TPEF and the achieved HDI of the six exemplary countries during the 2000-2014 period. The Absolute Decuupling Point (ADP, green) has been highlighted in the TPEF line of each country.

Figure 7 shows which industrial sectors (defined by the Eora database, Supplementary Table 1) present higher energy reductions in the exemplary countries. Direct electricity consumed at homes been included in the industrial sector 24 ("Private Households"). A sectorial divergence is notorious. While in some countries, such as HUN or GBR, reduction in "Private households" energy consumption has been significant (3-4\%), in other countries, such as JPN or ITA, reductions in "Construction" sector have been more relevant (1-4\%). "Electricity, Gas and Water" and "Petroleum, Chemical and Non-Metallic" sectors have notorious reductions in almost all the countries. It has been observed that "Transportation" sector has not any significant reduction in any of the exemplary countries. "Electrical and Machinery" sector has variations in reductions; JPN has been able to reduce the energy consumed in this sector, while the rest of the exemplary countries are increasing the energy consumption in it. Trade sectors have generally suffer a slight reduction, while "Financial and Business activities" have experienced a generally slight increase. 


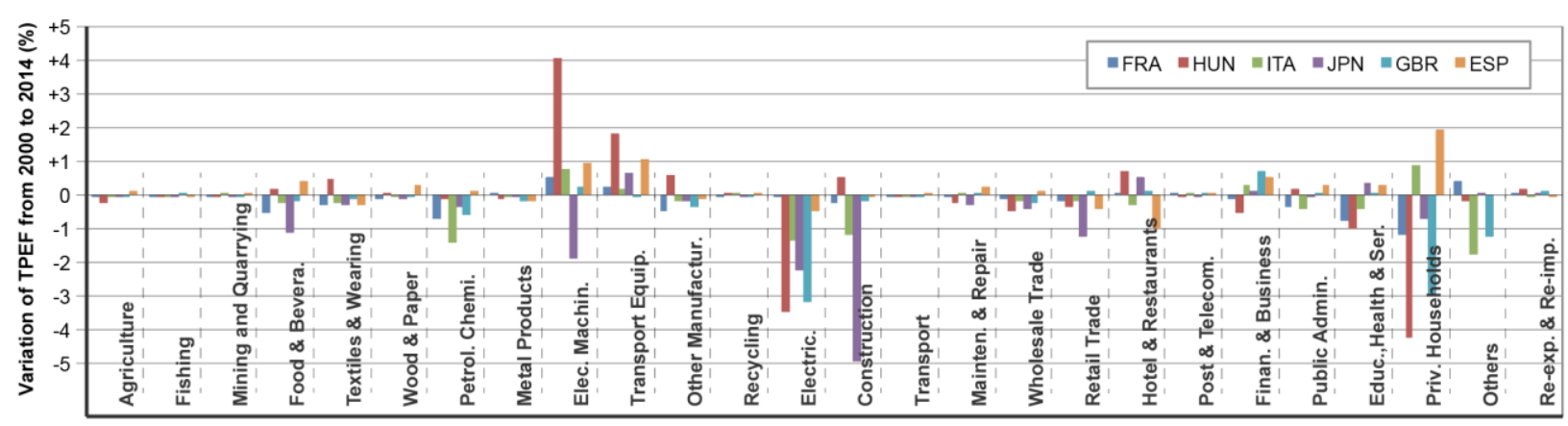

Figure 7: Percent increase or decrease of energy consumption by sector (according to TPEF accounts) from 2000 to 2014 for the six exemplary countries.

\subsection{Temporary or permanent decoupling}

In this subsection, countries that have manifested a temporary decoupling in one or more years have been identified. Figure 8 shows that from the 126 countries analysed, taking into ccount the TPEF values, 89 have reached a permanent or temporary decoupling; from which 27 ( s s wn 11 Figure 3) are permanently decoupled and 62 have experienced a temporary decoupling. Temnor, v ecoupling means that at least in one year have been able to reduce TPEF while increasin their HDI alue. The TPEF value at which these countries have reach the temporary decoupling, is dr stically lifferent among countries. Some countries have been able to decouple with a TPEF inferior than $N \mathrm{Nh} \cdot \mathrm{cap}^{-1} \cdot \mathrm{yr}^{-1}$ (especially in Africa), whereas others have decoupled with a TPEF superior that $180 \mathrm{MWh} \cdot \mathrm{cap}^{-1} \cdot \mathrm{yr}^{-1}$. Achieving a temporary decoupling - even if less relevant than achieving an av rage bbsolute decoupling -, reveals the possible 62 candidate countries that could be able to re ch a na...ned decoupling in the incoming years (Supplementary Figure 2 and Supplementary Figui, 3).
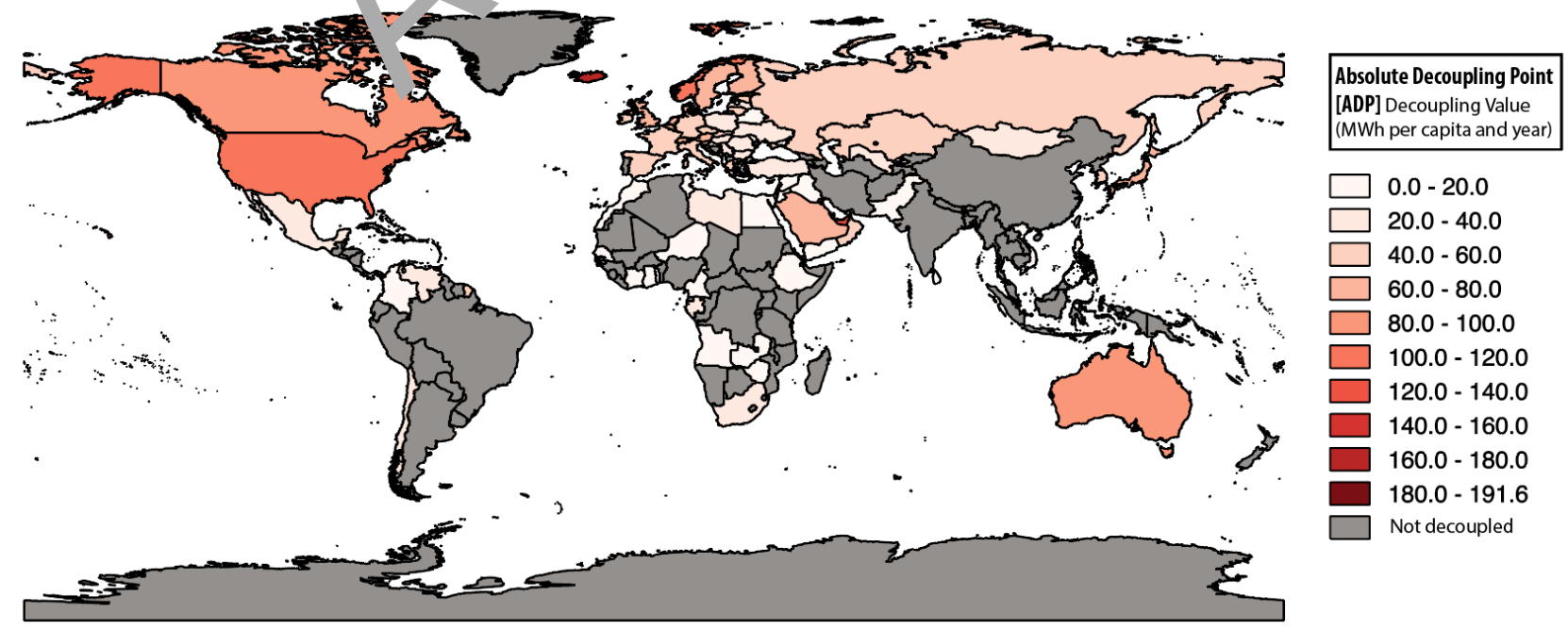

Figure 8: 89 countries have been temporarily or permanently decoupled during the 2000-2014 period according TPEF accounts. 


\section{Discussion:}

\subsection{General discussion:}

In order to achieve global energy justice (Sovacool et al., 2016) and gain a global equal share of energy resources, most developed countries should reduce their current energy consumption (as explained Section 1). Nevertheless this reduction does not imply necessarily a reduction of citizen's wellbeing. The possibility of meeting a decoupling between energy consumption and HDI allows countries to transit towards a low socio-environmental impact energy system. Furthermore, this could enhance a fair share of global energy resources among countries, boosting international energy justice. In this study, six countries have been identified (FRA, HUN, ITA, JPN, GBR, ESP), which are already experiencing the decoupling phenomenon in a maintained way. Until the present day, mainly the "degrowth movement", recognised by the scientific community (Weiss and Cattaneo, 2017), has made clear proposals for reducing resources consumption in order to reach better global living standards. The energy cegrowth proposal, due to the possibility of increasing development (welfare) while reducing energy nsu nption, has the potential to become an international energy transition strategy.

In order to analyse DI, this study shows that consumption-bas a a co, ws must be used; since results are more complete than traditional TPES-based analyses. $C$ aly foo rint based accounts are able to reflect the current reality of the internationally globalised goods a d servis s market. The use of TPEF data, instead of TPES, brings most of the analysed countries towarus a more coupled situation between energy consumption and HDI. Calculations that have bee offer an interesting but partial perspective of the energy consumption decoupling, generating a "virtual decoupling" in numerous countries "th a AUs, CAN, LUX, CHE, etc.). This study shows that footprint accounts need to be taken into acc 'nt t avoid "virtual decoupling", not only in developed countries, but even in non-developed ones. $\mathrm{Th}_{\mathrm{h}}$ is particularly significant when defining worldwide energetically exemplary countries to ' $\mathrm{C}$ ' $\mathrm{h}$ w.

As a positive result of $\mathrm{t}$ research, it has been noted that absolute decoupling has been permanently or partially achieved within very different energy consumption and HDI values by 89 countries (Figure 8). Absolute decoupling has been achieved from high-energy consumption countries as QAT, ISL and LUX (with a TPEF between 192-169 MWh. $\mathrm{cap}^{-1} \cdot \mathrm{yr}^{-1}$ and a HDI between 0.83-0.89), to low energy consumption ones as YEM, SEN and NER (with a TPEF between 4-2 MWh. $\mathrm{cap}^{-1} \cdot \mathrm{yr}^{-1}$ and a HDI between 0.35-0.49). This gives an optimistic nuance to the incoming necessary energy transition process, meaning that regardless of the energy intensity of a country, there is room of improvement for energy consumption reductions in every national reality and maintain or increase the HDI. Furthermore, it could be observed in Figure 4, shows that more countries are able to reach an absolute decoupling in the last period (2012-2014) than previously, showing a clear international tendency to move towards lower energy consumption realities.

This study shows that according to the analysed 126 countries, there is much left to do to trigger the necessary worldwide decoupling required to reach sufficient energy consumption reduction in developed countries, and boost the increase of HDI in less-developed ones to achieve the sustainable use of global 
energy resources, with low socio-environmental impacts. Nevertheless, positive performances have been found, observing that more countries have been achieving important decoupling targets in recent years, especially between 2012 and 2014.

\subsection{Exemplary countries:}

Although achieving a temporary absolute decoupling can frequently occur, maintaining this tendency in the long-term, in order to clearly reduce the energy consumption of a country while increasing its HDI, has been found to be challenging. From the 126 countries analysed, only 27 have shown an average absolute decoupling during the total year gap of 2000-2014 (Figure 3), and only 6 of them, within the HDI above 0.8 , have shown a maintained absolute decoupling during the last three year gaps, 2004-2008, 2008-2012 and 2012-2014 (Figure 4 and Figure 5). These exemplary countries show three relevant aspects.

Firstly, the gradual energy reduction is a constant trend in most of them avoiding drastic reductions. Energy reductions have been achieved inside the country boundaries (nost probably due to the energy efficiency achievements: eco-efficiency and innovation), but also wi nin re im orted energy embodied in goods and services. Reached energy reductions during 14 yea av Len significant, and three of the exemplary countries (ESP, ITA, HUN) have been able reduc aro nd 30\% of their TPEF. According to the sectorial distribution of reductions, achievements the ele tric production sector have been notorious in all countries, as well as in the petrochemical sector. Kunuctions in the construction and the household sectors are also relevant in some countries. Thu it is noticed that each country has its own strategy to reduce the TPEF, reducing energy consump on fr m significantly different economic sectors.

Secondly, the GFC has positively $n$ ach 1 in the exemplary countries regarding this scope, provoking ulterior reductions in their energy , nsu. ption while still increasing the HDI value. This allows citizens to understand the crisis as an opportu. ity (schneider et al., 2010).

Finally, all of the ex ary ary net embodied energy importers. This should be taken into account to improve int "ational relations promoting the support to most industrial producer countries, enhancing their increase o HDI while maintaining low levels for their per capita energy consumption. The recognition of the current imports of embodied energy in goods and services is a key factor. Importer countries need to be aware of the privileges that this brings to them (such as to allow an easier decoupling between energy consumption and welfare), and fair economic payments for imported embodied energy should be promoted. Compensation systems, such as the ones developed in carbon footprints in global scale (Pezzey and Jotzo, 2013), (Meng et al., 2018) or in ecosystem services in a more national or regional scale (Reed et al., 2017), could be implemented in the energy field.

\section{Conclusions and Policy Implications}

In the current globalised market, with large amount of goods and service exchanges among countries, it is compulsory to take into account the energy embodied in trade if an integral energy consumption diagnosis 
is desired. Countries can no longer understand their energy consumption accounts using TPES data directly drawn from the International Energy Agency database. Instead, TPES data needs to be complemented with TPEF calculations in order to avoid distortion of energy consumption pattern realities.

Exemplary countries, the ones that have achieved a maintained decoupling among consumed energy and improved HDI, have developed it via gradual energy consumption reductions as opposed to drastic energy consumption reduction performances. These reductions could be achieved by two paths; firstly by enhancing the integration of eco-efficiency and innovation tools within national boundaries (in particular within the electricity, petrochemical, construction and private houses sectors), and secondly via supporting the reduction of imported energy embodied in products and services from other countries which in turn triggers energy sovereignty. Despite the lack of clearly identified environmentally sustainable and socially fair global energy threshold, most developing countries seem to have a margin to increase their energy consumption in order to increase their HDI. However, this increase could be supported and expedited by international collaborations with energy efficient standards across develop ig countries through Kyoto Protocol-type clean development mechanisms or technology transfers (Or'EP, 198 ).

The study shows, that economic crises are an opportunity to gain de nur ing. In all of the six exemplary countries, the 2009 Global Financial Crisis (GFC) enhar a d t eir en ergy reduction while increasing their HDI.

Net embodied-energy exporter countries have been to nd especially weak when trying to achieve a decoupling reality; thus, in order to create a $\&$ bal absolute decoupling trend, solidarity towards and collaboration with net embodied-energy xpor $r$ countries should be increased. Building upon the recognition of trade in embodied enf $s, \mathrm{t}, \mathrm{d}$ and on quantitative information on energy footprints, international cooperation on reduc, g g, bal energy demand should be designed.

This work contributes to "Goal, of $\sim J$ G (UN, 2015), promoting insights to reach a sustainable energy system for all individ ${ }^{-1}$ s. The vor $\mathrm{c}$ also contributes towards the achievement of "Goal 10" of the SDG, fostering the reduction f ; equality among countries, and "Goal 12", enhancing sustainable consumption patterns.

\section{Acknowledgment}

The authors are grateful for the provided funding to the Erasmus Panther Programme coordinated by Warsaw University of Technology, and backed by the Sustainability Assessment Program (SAP) of the University of New South Wales (UNSW Sydney) and the University of the Basque Country (UPV/EHU), to make the 10-month research stay possible at UNSW Sydney, where this paper has been developed (Grant reference: Erasmus Panther PN/TG1/UNSW/PhD/02/2017). The authors also thank Hung Pham for his patience and support in Matlab coding. The authors thank James Hayes, Marian Arante and Anthony Coxeter for their valuable contribution as professional English editors within this project. 


\section{References}

Akizu, O., Bueno, G., Barcena, I., Kurt, E., Topaloğlu, N., Lopez-Guede, J.M., 2018. Contributions of Bottom-Up Energy Transitions in Germany: A Case Study Analysis. Energies 11, 849. https://doi.org/10.3390/en11040849

Akizu, O., Urkidi, L., Bueno, G., Lago, R., Barcena, I., Mantxo, M., Basurko, I., Lopez-Guede, J.M., 2017. Tracing the emerging energy transitions in the Global North and the Global South. Int. J. Hydrog. Energy. https://doi.org/10.1016/j.ijhydene.2017.04.297

Arto, I., Capellán-Pérez, I., Lago, R., Bueno, G., Bermejo, R., 2016. The energy requirements of a developed world. Energy Sustain. Dev. 33, 1-13. https://doi.org/10.1016/j.esd.2016.04.001

Barrett, J., Peters, G., Wiedmann, T., Scott, K., Lenzen, M., Roelich, K., Quéré, C.L., 2013. Consumption-based GHG emission accounting: a UK case st dy. Clim. Policy 13, 451470. https://doi.org/10.1080/14693062.2013.788858

Bullard, C.W., Foster, C.Z., 1976. On decoupling energy and FNP growth. Energy 1, 291-300. https://doi.org/10.1016/0360-5442(76)90004n

Capellán-Pérez, I., de Castro, C., Arto, I., 2017. Assê sing vulnerabilities and limits in the transition to renewable energies: Land requm nents under $100 \%$ solar energy scenarios. Renew. Sustain. Energy Rev. 77, 760 - 82. https://doi.org/10.1016/j.rser.2017.03.137

Capellán-Pérez, I., Mediavilla, M., de ( astro C., Carpintero, Ó., Miguel, L.J., 2014. Fossil fuel depletion and socio-econs ic s enarios: An integrated approach. Energy 77, 641-666. https://doi.org/10.1016/1.e. erg, 2014.09.063

Chen, B., Li, J.S., Wu, X.I Ha „M.Y., Zeng, L., Li, Z., Chen, G.Q., 2018. Global energy flows embodied in 1 ter - inal trade: A combination of environmentally extended input-output analysis and complex network analysis. Appl. Energy 210, 98-107. https://doi.org/10.1016/j.apenergy.2017.10.113

Chen, C.-Z., Lin, Z.-S., 2008. Multiple timescale analysis and factor analysis of energy ecological footprint growth in China 1953-2006. Energy Policy 36, 1666-1678. https://doi.org/10.1016/j.enpol.2007.11.033

Chen, G.Q., Wu, X.F., 2017. Energy overview for globalized world economy: Source, supply chain and sink. Renew. Sustain. Energy Rev. 69, 735-749. https://doi.org/10.1016/j.rser.2016.11.151

Chen, Z.-M., Chen, G.Q., 2013. Demand-driven energy requirement of world economy 2007: A multi-region input-output network simulation. Commun. Nonlinear Sci. Numer. Simul. 18, 1757-1774. https://doi.org/10.1016/j.cnsns.2012.11.004 
Cullen, J.M., Allwood, J.M., Borgstein, E.H., 2011. Reducing Energy Demand: What Are the Practical Limits? Environ. Sci. Technol. 45, 1711-1718. https://doi.org/10.1021/es102641n

de Freitas, L.C., Kaneko, S., 2011. Decomposing the decoupling of CO2 emissions and economic growth in Brazil. Ecol. Econ. 70, 1459-1469. https://doi.org/10.1016/j.ecolecon.2011.02.011

Diakoulaki, D., Mandaraka, M., 2007. Decomposition analysis for assessing the progress in decoupling industrial growth from $\mathrm{CO} 2$ emissions in the EU manufacturing sector. Energy Econ., Modeling of Industrial Energy Consumption 29, 636-664. https://doi.org/10.1016/j.eneco.2007.01.005

Eisenstein, M., 2017. How social scientists can help to shape climate policy. Nature 551, 142-144. https://doi.org/10.1038/d41586-017-07418-y

Fouquet, R., 2017. Make low-carbon energy an integral part c thr kno ledge economy. Nature 551, S141. https://doi.org/10.1038/d41586-017-075

Galli, A., Wiedmann, T., Ercin, E., Knoblauch, J., Eu ng B., Giljum, S., 2012. Integrating Ecological, Carbon and Water footprint in a "Fo tprint Family" of indicators: Definition and role in tracking human pressure $\mathrm{n}$ the planet. Ecol. Indic., The State of the Art in Ecological Footprint: Tra $\mathrm{r}$ and Applications 16, 100-112. https://doi.org/10.1016/j.ecolind.2 $111,6.017$

García-Olivares, A., 2016. Ene oy r a sustainable post-carbon society. Sci. Mar. 80, 257-268.

Gies, E., 2017. The real cost o enc oy. Nature 551, 145-147. https://doi.org/10.1038/d41586-01707510-3

Goldemberg, J., Sique ir Prado, L.T., 2011. The decline of the world's energy intensity. Energy Policy 39, 1802-1805. https://doi.org/10.1016/j.enpol.2011.01.013

Grabl, H., Kokott, J., Kulessa, M., Luther, J., Nuscheler, F., Sauerbon, R., Schellnhuber, H.J., Schulze, E.D., 2004. World in Transition: Towards Sustainable Energy Systems. Earthscan.

Hansen, J.P., Narbel, P.A., Aksnes, D.L., 2017. Limits to growth in the renewable energy sector. Renew. Sustain. Energy Rev. 70, 769-774. https://doi.org/10.1016/j.rser.2016.11.257

Heeren, N., Wallbaum, H., Jakob, M., 2012. Towards a 2000 Watt society - assessing buildingspecific saving potentials of the Swiss residential building stock. Int. J. Sustain. Build. Technol. Urban Dev. 3, 43-49. https://doi.org/10.1080/2093761X.2012.673917

Heinonen, J., Junnila, S., 2014. Residential energy consumption patterns and the overall housing energy requirements of urban and rural households in Finland. Energy Build. 76, 295-303. https://doi.org/10.1016/j.enbuild.2014.02.079 
Hoekstra, A.Y., Wiedmann, T.O., 2014. Humanity's unsustainable environmental footprint. Science 344, 1114-1117. https://doi.org/10.1126/science.1248365

Hsiang, S., Kopp, R., Jina, A., Rising, J., Delgado, M., Mohan, S., Rasmussen, D.J., Muir-Wood, R., Wilson, P., Oppenheimer, M., Larsen, K., Houser, T., 2017. Estimating economic damage from climate change in the United States. Science 356, 1362-1369. https://doi.org/10.1126/science.aal4369

Huijbregts, M.A.J., Hellweg, S., Frischknecht, R., Hendriks, H.W.M., Hungerbühler, K., Hendriks, A.J., 2010. Cumulative Energy Demand As Predictor for the Environmental Burden of Commodity Production. Environ. Sci. Technol. 44, 2189-2196. https://doi.org/10.1021/es902870s

Inman, M., 2013. The True Cost of Fossil Fuels. Sci. Am. 308, 58-61. https://doi.org/10.1038/scientificamerican0413-58

Inman, M., 2008. Carbon is forever. Nat. Re p. Clin Change 156-158. https://doi.org/10.1038/climate.2008.122

International Energy Agency, 2015. Energy Balanc s 2015

IPCC, 2015. Fifth Assessment Report (AR5), Clin te Cha ige 2014.

Jacobson, M.Z., Delucchi, M.A., 2011. Prov ling all global energy with wind, water, and solar power, Part I: Technologies, eneros re urces, quantities and areas of infrastructure, and materials. Energy Policy 39, 1154 116). https://doi.org/10.1016/j.enpol.2010.11.040

Jacobson, M.Z., Delucchi, M.A . B. ver, _.A.F., Goodman, S.C., Chapman, W.E., Cameron, M.A., Bozonnat, C., Choba'i, Clonts, H.A., Enevoldsen, P., Erwin, J.R., Fobi, S.N., Goldstrom, C K., Ho ne sy, E.M., Liu, J., Lo, J., Meyer, C.B., Morris, S.B., Moy, K.R., O’Neill, P.L., 'rov, I., Redfern, S., Schucker, R., Sontag, M.A., Wang, J., Weiner, E., Yachanin, A.S., 2017. 100\% Clean and Renewable Wind, Water, and Sunlight All-Sector Energy Roadmaps for 139 Countries of the World. Joule 1, 108-121. https://doi.org/10.1016/j.joule.2017.07.005

Jacobson, M.Z., Delucchi, M.A., Bazouin, G., Bauer, Z.A.F., Heavey, C.C., Fisher, E., Morris, S.B., Piekutowski, D.J.Y., Vencill, T.A., Yeskoo, T.W., 2015. 100\% clean and renewable wind, water, and sunlight (WWS) all-sector energy roadmaps for the 50 United States. Energy Environ. Sci. 8, 2093-2117. https://doi.org/10.1039/C5EE01283J

Kaltenegger, O., Löschel, A., Pothen, F., 2017. The effect of globalisation on energy footprints: Disentangling the links of global value chains. Energy Econ., Seventh Atlantic Workshop in Energy and Environmental Economics 68, 148-168. https://doi.org/10.1016/j.eneco.2018.01.008 
Kanemoto, K., Lenzen, M., Peters, G.P., Moran, D.D., Geschke, A., 2012. Frameworks for Comparing Emissions Associated with Production, Consumption, And International Trade. Environ. Sci. Technol. 46, 172-179. https://doi.org/10.1021/es202239t

Krugmann, H., Goldemberg, J., 1983. The energy cost of satisfying basic human needs. Technol. Forecast. Soc. Change 24, 45-60. https://doi.org/10.1016/0040-1625(83)90062-8

Kucukvar, M., Onat, N.C., Haider, M.A., Shaikh, M.A., 2017. A Global Multiregional Life Cycle Sustainability Assessment of National Energy Production Scenarios until 2050. Presented at the International Conference on Industrial Engineering and Operations Management Bogota.

Lan, J., Malik, A., Lenzen, M., McBain, D., Kanemoto, K., 2016. A structural decomposition analysis of global energy footprints. Appl. Energy 163, 436-451. https://doi.org/10.1016/j.apenergy.2015.10.178

Lenzen, M., Kanemoto, K., Moran, D., Geschke, A., 2012. M ipp. g th Structure of the World Economy. Environ. Sci. Technol. 46, 8374-8381. h .p. $/ /$ org/10.1021/es300171x

Lenzen, M., Moran, D., Kanemoto, K., Geschke, A , , zU13. Bui ding Eora: A Global Multi-Region Input-Output Database at High Country a d Sect r Resolution. Econ. Syst. Res. 25, 20 49. https://doi.org/10.1080/09535314.2213.769938

Lenzen, M., Pade, L.-L., Munksgaard, I 904 ' CO2 Multipliers in Multi-region Input-Output Models. Econ. Syst. Res. 16, 391 112 https://doi.org/10.1080/0953531042000304272

Martínez, D.M., Ebenhack, B. V 208 . Understanding the role of energy consumption in human development through he . of saturation phenomena. Energy Policy 36, 1430-1435. https://doi.ore/10.10 \$/j.f npol.2007.12.016

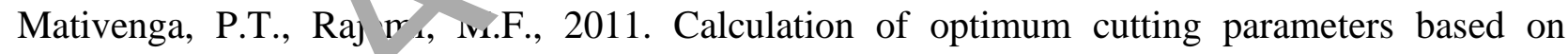
minimum eneisy footprint. CIRP Ann. - Manuf. Technol. 60, 149-152. https://doi.org/10.1016/j.cirp.2011.03.088

Mazumder, S., 2018. Inflation in Europe after the Great Recession. Econ. Model. https://doi.org/10.1016/j.econmod.2017.12.014

Mazur, A., 2011. Does increasing energy or electricity consumption improve quality of life in $\begin{array}{lllll}\text { industrial } & \text { nations? } & \text { Energy } & \text { Policy } & 3968-2572 .\end{array}$ https://doi.org/10.1016/j.enpol.2011.02.024

Meadows, D.H., Meadows, D.L., Randers, J., Behrens III, W.W., 1972. The Limits to growth: a report for the Club of Rome's project on the predicament of mankind. Universe Books.

Meng, X., Yao, Z., Nie, J., Zhao, Y., 2018. Make or buy? It is the question: A study in the presence of carbon tax. Int. J. Prod. Econ. 195, 328-337. https://doi.org/10.1016/j.ijpe.2017.10.029 
Mielnik, O., Goldemberg, J., 2002. Foreign direct investment and decoupling between energy and gross domestic product in developing countries. Energy Policy 30, 87-89. https://doi.org/10.1016/S0301-4215(01)00080-5

Miller, R.E., Blair, P.D., 2009. Input-Output Analysis: Foundations and Extensions. Cambridge University Press.

Min, J., Rao, N.D., 2017. Estimating Uncertainty in Household Energy Footprints. J. Ind. Ecol. n/a-n/a. https://doi.org/10.1111/jiec.12670

Moran, D., Wood, R., 2014. Convergence Between the Eora, Wiod, Exiobase, and Openeu's Consumption-Based Carbon Accounts. Econ. Syst. Res. 26, 245-261. https://doi.org/10.1080/09535314.2014.935298

Moreau, V., Vuille, F., 2018. Decoupling energy use and economic growth: Counter evidence from structural effects and embodied energy in trade $A_{1}$ ol. Energy 215, 54-62. https://doi.org/10.1016/j.apenergy.2018.01.044

Munksgaard, J., Pedersen, K.A., 2001. CO2 accounts for tomies: producer or consumer responsibility? Energy Policy 29, 327-334 altps:// 'oi.c g/10.1016/S0301-4215(00)001208

Nilsson, L.J., 1993. Energy intensity trends ir 31 industrial and developing countries 1950-1988. Energy 18, 309-322. https://doi.or-10. 916/0360-5442(93)90066-M

OECD, (Organization for Economic Co- ner ion and Development), 2002. Indicators to measure decoupling of environt ent.' pressure from economic growth. Sustainable Development. SG/SD (2002).

Oita, A., Malik, A. Kanen to. K., Geschke, A., Nishijima, S., Lenzen, M., 2016. Substantial nitrogen poll ti n embedded in international trade. Nat. Geosci. 9, 111-115. https://doi.org/11.1038/ngeo2635

O’Neill, D.W., Fanning, A.L., Lamb, W.F., Steinberger, J.K., 2018. A good life for all within planetary boundaries. Nat. Sustain. 1, 88-95. https://doi.org/10.1038/s41893-018-0021-4

Owen, A., Brockway, P., Brand-Correa, L., Bunse, L., Sakai, M., Barrett, J., 2017. Energy consumption-based accounts: A comparison of results using different energy extension vectors. Appl. Energy 190, 464-473. https://doi.org/10.1016/j.apenergy.2016.12.089

Pargman, D., Eriksson, E., Höök, M., Tanenbaum, J., Pufal, M., Wangel, J., 2017. What if there had only been half the oil? Rewriting history to envision the consequences of peak oil. Energy Res. Soc. Sci., Narratives and Storytelling in Energy and Climate Change Research 31, 170-178. https://doi.org/10.1016/j.erss.2017.06.007 
Pasten, C., Santamarina, J.C., 2012. Energy and quality of life. Energy Policy, Special Section: Fuel Poverty Comes of Age: Commemorating 21 Years of Research and Policy 49, 468476. https://doi.org/10.1016/j.enpol.2012.06.051

Peters, G.P., 2008. From production-based to consumption-based national emission inventories. Ecol. Econ. 65, 13-23. https://doi.org/10.1016/j.ecolecon.2007.10.014

Peters, G.P., Hertwich, E.G., 2008. Post-Kyoto greenhouse gas inventories: production versus consumption. Clim. Change 86, 51-66. https://doi.org/10.1007/s10584-007-9280-1

Pezzey, J.C.V., Jotzo, F., 2013. Carbon tax needs thresholds to reach its full potential. Nat. Clim. Change 3, 1008-1011. https://doi.org/10.1038/nclimate2054

Puig, R., Fullana-i-Palmer, P., Baquero, G., Riba, J.-R., Bala, A., 2013. A Cumulative Energy Demand indicator (CED), life cycle based, for industrial waste management decision making. Waste Manag. 33, 2789-2797. https://doi.org/10.1016/J vasman.2013.08.004

Reed, M.S., Allen, K., Attlee, A., Dougill, A.J., Evans, K.L., Ken er, J. )., Hoy, J., McNab, D., Stead, S.M., Twyman, C., Scott, A.S., Smyth, M A., Sᄂ. _er, L.C., Whittingham, M.J., 2017. A place-based approach to payments or eco vste n services. Glob. Environ. Change 43, 92-106. https://doi.org/10.1016/j.gloen cha.20 6.12.009

Rocco, M.V., Forcada Ferrer, R.J., Colombo E., 2018. Understanding the energy metabolism of World economies through the jo:- us of Production- and Consumption-based energy accountings. Appl. Energy 211 5 n-6 3. https://doi.org/10.1016/j.apenergy.2017.10.090

Rockström, J., Steffen, W., N cnc K., Sersson, A., Chapin, F.S., Lambin, E.F., Lenton, T.M., Scheffer, M., Folke, C. Sc. د"nhuber, H.J., Nykvist, B., de Wit, C.A., Hughes, T., van der Leeuw, S., Rrdhe, H Sörin, S., Snyder, P.K., Costanza, R., Svedin, U., Falkenmark, M., Karlberg, L., ( or Al, k.W., Fabry, V.J., Hansen, J., Walker, B., Liverman, D., Richardson, K., Crutzen, P., Joley, J.A., 2009. A safe operating space for humanity. Nature 461, 472475. https://doi.org/10.1038/461472a

Rodrigues, J.F.D., Moran, D., Wood, R., Behrens, P., 2018. Uncertainty of Consumption-Based Carbon Accounts. Environ. Sci. Technol. https://doi.org/10.1021/acs.est.8b00632

Röhrlich, M., Mistry, M., Martens, P.N., Buntenbach, S., Ruhrberg, M., Dienhart, M., Briem, S., Quinkertz, R., Alkan, Z., Kugeler, K., 2000. A method to calculate the cumulative energy demand (CED) of lignite extraction. Int. J. Life Cycle Assess. 5, 369-373. https://doi.org/10.1007/BF02978675

Schneider, F., Kallis, G., Martinez-Alier, J., 2010. Crisis or opportunity? Economic degrowth for social equity and ecological sustainability. Introduction to this special issue. J. Clean. Prod., Growth, Recession or Degrowth for Sustainability and Equity? 18, 511-518. https://doi.org/10.1016/j.jclepro.2010.01.014 
Sen, A., 1992. Inequality Reexamined. Harvard University Press, New York.

Slaper, T.F., Hall, T.J., 2011. The Triple Bottom Line: What Is It and How Does It Work? Indiana Bus. Rev. Volume 86, No. 1.

Sorrell, S., 2015. Reducing energy demand: A review of issues, challenges and approaches. Renew. Sustain. Energy Rev. 47, 74-82. https://doi.org/10.1016/j.rser.2015.03.002

Sovacool, B.K., Heffron, R.J., McCauley, D., Goldthau, A., 2016. Energy decisions reframed as justice and ethical concerns. Nat. Energy 1, 16024. https://doi.org/10.1038/nenergy.2016.24

Steckel, J.C., Brecha, R.J., Jakob, M., Strefler, J., Luderer, G., 2013. Development without energy? Assessing future scenarios of energy consumption in developing countries. Ecol. Econ. 90, 53-67. https://doi.org/10.1016/j.ecolecon.2013.02.006

Steffen, W., Richardson, K., Rockström, J., Cornell, S.E., Fetzer I., Bennett, E.M., Biggs, R., Carpenter, S.R., Vries, W. de, Wit, C.A. de, Folke, C., C.erm ?, D., Heinke, J., Mace, G.M., Persson, L.M., Ramanathan, V., Reyers, B., S̈̈.1. 2015. Planetary boundaries: Guiding human development on a nangil. lanet. Science 347, 1259855. https://doi.org/10.1126/science.1259855

Steinberger, J.K., Roberts, J.T., 2010. From onstraint to sufficiency: The decoupling of energy and carbon from human needs, 1275 2005. Ecol. Econ., Special Section: Ecological Distribution Conflicts 70, 425-43 ht $\mathrm{ps}$ ://doi.org/10.1016/j.ecolecon.2010.09.014

Stulz, R., Tanner, S., Sigg, R., 01 Chater 16 - Swiss 2000-Watt Society: A Sustainable Energy Vision for the Futu. N Sioshansi, F.P. (Ed.), Energy, Sustainability and the Environment But erworth-Heinemann, Boston, pp. 477-496. https://doi.org/ 0 101v/B978-0-12-385136-9.10016-6

Tapio, P., 2005. Towar a theory of decoupling: degrees of decoupling in the EU and the case of road traffic in Finland between 1970 and 2001. Transp. Policy 12, 137-151. https://doi.org/10.1016/j.tranpol.2005.01.001

Teske, S., Sawyer, S., Schäfer, O., Pregger, T., Simon, S., Naegler, T., 2015. Energy [R] evolution - a sustainable world energy outlook 2015.

UN, 2015. Transforming our World: the 2030 Agenda for Sustainable Development Annex $\mathrm{A} / \mathrm{RES} / 70 / 1$.

UNDP (Ed.), 2017. Human Development Report 2016: Human Development for Everyone. And Technical Notes. United Nations, New York, NY.

UNDP, 2015. Trends in the Human Development Index, 1990-2015 [WWW Document]. URL http://hdr.undp.org/en/composite/trends 
UNEP, U.N., 1998. KYOTO PROTOCOL TO THE UNITED NATIONS FRAMEWORK CONVENTION ON CLIMATE CHANGE.

UNEP, U.N.E.P., 2014. Decoupling 2: technologies, opportunities and policy options. UNEP.

UNEP, U.N.E.P., 2011. Decoupling: natural resource use and environmental impacts from economic growth. UNEP.

Wang, H., 2011. Decoupling Measure between Economic Growth and Energy Consumption of China. Energy Procedia, 2010 International Conference on Energy, Environment and Development - ICEED2010 5, 2363-2367. https://doi.org/10.1016/j.egypro.2011.03.406

Weiss, M., Cattaneo, C., 2017. Degrowth - Taking Stock and Reviewing an Emerging Academic Paradigm. Ecol. Econ. 137, 220-230. https://doi.org/10.1016/j.ecolecon.2017.01.014

Wiedmann, T., 2009. A first empirical comparison of energy Footprints embodied in trade MRIO versus PLUM. Ecol. Econ., Methodological Advan ements in the Footprint Analysis 68, 1975-1990. https://doi.org/10.1016/j.ecoler on. 708.15 .023

Wiedmann, T., Lenzen, M., 2018. Environmental and soci Geosci. 11, 314-321. https://doi.org/10.103/s4156 -01,-0113-9

Wiedmann, T., Lenzen, M., Turner, K., Barrett, '., 200 . Examining the global environmental impact of regional consumption activit is - Part 2: Review of input-output models for the assessment of environmental ir embodied in trade. Ecol. Econ. 61, 15-26. https://doi.org/10.1016/j.ecoleron 200f .12.003

Wiedmann, T.O., Schandl, H., Ten_ n, M., Moran, D., Suh, S., West, J., Kanemoto, K., 2015. The material footprint of ntions. Proc. Natl. Acad. Sci. 112, 6271-6276. https://doi.orc/10.10, 2/pr as.1220362110

Wood, R., Stadler, K., S' nas, M., Bulavskaya, T., Giljum, S., Lutter, S., Tukker, A., 2018. Growth in Environment: Footprints and Environmental Impacts Embodied in Trade: Resource Efficiency Indicators from EXIOBASE3. J. Ind. Ecol. n/a-n/a. https://doi.org/10.1111/jiec.12735

Wu, X.F., Chen, G.Q., 2017. Global primary energy use associated with production, consumption and international trade. Energy Policy 111, 85-94. https://doi.org/10.1016/j.enpol.2017.09.024

Wu, Y., Zhu, Q., Zhu, B., 2018. Comparisons of decoupling trends of global economic growth and energy consumption between developed and developing countries. Energy Policy 116, 3038. https://doi.org/10.1016/j.enpol.2018.01.047

WWF, 2011. The energy report: 100\% renewable energy by 2050. WWF, Ecofys, OMA, Switzerland and Netherlands. 
Zhang, C., Chen, W.-Q., Liu, G., Zhu, D.-J., 2017. Economic Growth and the Evolution of Material Cycles: An Analytical Framework Integrating Material Flow and Stock Indicators. Ecol. Econ. 140, 265-274. https://doi.org/10.1016/j.ecolecon.2017.04.021

Zhang, D., Caron, J., Winchester, N., 2018. Sectoral Aggregation Error in the Accounting of Energy and Emissions Embodied in Trade and Consumption. J. Ind. Ecol. n/a-n/a. https://doi.org/10.1111/jiec.12734

Zhang, M., Song, Y., Su, B., Sun, X., 2015. Decomposing the decoupling indicator between the economic growth and energy consumption in China. Energy Effic. 8, 1231-1239. https://doi.org/10.1007/s12053-015-9348-0 


\section{Supplementary Material}

Next supplementary figures, tables and notes have been added to support the better understanding of the study.

Supplementary Note 1: The next validation shows how the original formula (left side of Equation 7) and the one used in this research to create Equation 8 (right side of Equation 7), are the identical.

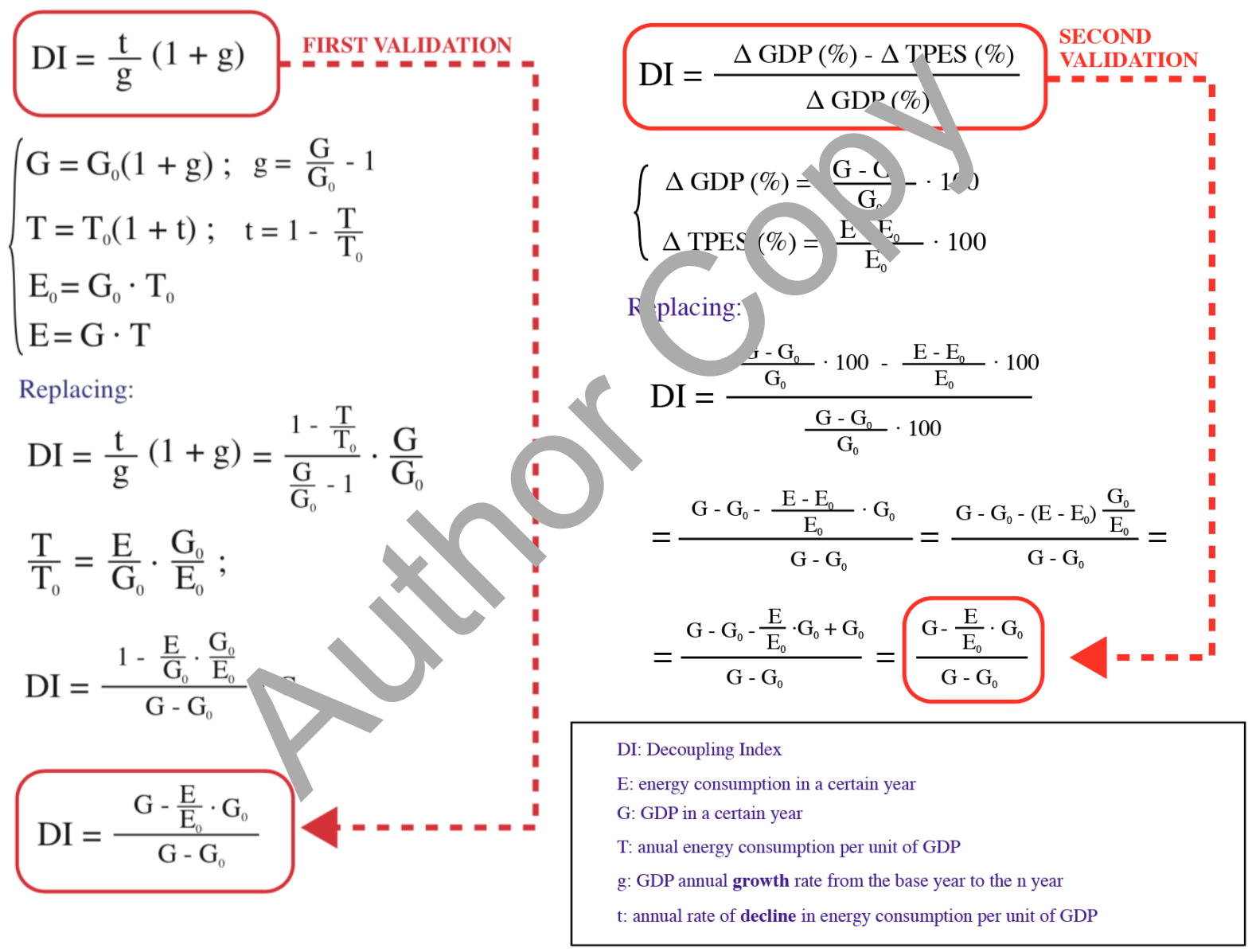

Supplementary Note 2: In order to offer the full quadrant range of answers to Equation 8, in the algorithm used in the calculations, ARCTAN limitations have been corrected using "if" commands in Matlab. This way authors were able to amplify the -90 to 90 results range to -180 to 180. The DI value was corrected as follows:

if ANGLE ARCTAN $<0$ and DELTA_HDI $<0$

ANGLE ARCTAN = ANGLE ARCTAN +180;

elseif ANGLE ARCTAN $>0$ and DELTA_HDI $<0$

ANGLE ARCTAN = ANGLE ARCTAN -180; 
Supplementary Table 1: Matching between TPES data obtained form International Energy Agency (IEA) and Eora Database 26 sectors to create the TPES satellite data.

\begin{tabular}{|c|c|c|c|}
\hline \multirow{2}{*}{$\begin{array}{l}\text { Sector } \\
\text { number } \\
\text { (Eora) }\end{array}$} & \multirow[b]{2}{*}{ Sector Description (Eora) } & \multicolumn{2}{|c|}{ Sector matching (IEA) } \\
\hline & & Final Consumption IEA & Losses IEA \\
\hline 1 & Agriculture & L_82: Agriculture/forestry & - \\
\hline 2 & Fishing & L_83: Fishing & - \\
\hline 3 & Mining and Quarrying & L_63: Mining and quarrying & - \\
\hline 4 & Food \& Beverages & L_64: Food and tobacco & - \\
\hline 5 & $\begin{array}{l}\text { Textiles and Wearing } \\
\text { Apparel }\end{array}$ & L_68: Textile and leather & - \\
\hline 6 & Wood and Paper & $\begin{array}{l}\text { L_65: Paper, pulp and print } \\
\text { L_66: Wood and wood products }\end{array}$ & - \\
\hline 7 & $\begin{array}{l}\text { Petroleum, Chemical and } \\
\text { Non-Metallic Mineral } \\
\text { Products }\end{array}$ & $\begin{array}{l}\text { L_58: Chemical and petrochemical } \\
\text { L_59: Non-ferrous metals } \\
\text { L_60: Non-metallic minerals }\end{array}$ & $\begin{array}{l}\text { L_26: Coke ovens (transf.) } \\
\text { L_27: Patent fuel plants (transf.) } \\
\text { L_29: Oil refineries (transf.) } \\
\text { L_30: Petrochemical plants (transf.) } \\
\text { L31: Coal liquefaction plants (transf.) } \\
\text { L_34: Charcoal production plants (transf.) }\end{array}$ \\
\hline 8 & Metal Products & L_57: Iron and steel & L_24: Blast furnaces (transf.) \\
\hline 9 & Electrical and Machinery & L_62: Machinery & - \\
\hline 10 & Transport Equipment & L_61: Transport equipment & - \\
\hline 11 & Other Manufacturing & L_69: Non-specified (industry) & \\
\hline 12 & Recycling & - & -7 \\
\hline 13 & Electricity, Gas and Water & - & $\begin{array}{l}\text { I 10: in a vity producer electricity plants (transf.) } \\
\text { 16: Au prod or electricity plants (transf.) } \\
\text { L_17: Ma activity producer CHP plants (transf.) } \\
\text { 19: Main activity producer heat plants (transf.) } \\
\text { 20: Autoproducer heat plants (transf.) } \\
\text { L_21: Heat pumps (transf.) } \\
\text { L_22: Electric boilers (transf.) } \\
\text { L_36: Enemical heat for electricity production (transf.) } \\
\text { L_54: Losses }\end{array}$ \\
\hline 14 & Construction & L_67: Con ruction & L_28: BKB/peat briquette plants (transf.) \\
\hline 19 & Transport & $\overline{\mathrm{L}}$-70. Tran. & - \\
\hline 15 & Maintenance and Repair & & \\
\hline 16 & Wholesale Trade & & \\
\hline 17 & Retail Trade & & \\
\hline 18 & Hotels and Restaurarts & L_81: Commercial and public & \\
\hline 20 & $\begin{array}{l}\text { Post and } \\
\text { Telecomn nic.. }\end{array}$ & $\begin{array}{l}\text { Services (Proportionally divided } \\
\text { according to the Eora } 26 \text { "Z" }\end{array}$ & - \\
\hline 21 & $\begin{array}{l}\text { Financial It rme ath nd } \\
\text { Business Ac }\end{array}$ & matrix). & \\
\hline 22 & Public Admin ration & & \\
\hline 23 & $\begin{array}{l}\text { Education, Hearth and Other } \\
\text { Services }\end{array}$ & & \\
\hline 24 & Private Households & L_80: Residential & - \\
\hline 25 & Others & $\begin{array}{l}\text { L_84: Non-specified (other) } \\
\text { L_85: Non-energy use }\end{array}$ & $\begin{array}{l}\text { L_12: Transfers } \\
\text { L_13: Statistical differences }\end{array}$ \\
\hline 26 & Re-export \& Re-import & - & - \\
\hline TOTAL & $100 \%$ & & $100 \%$ \\
\hline
\end{tabular}


A) Increase (AUS) and decrease (CHN) of energy consumption with TPEF accounts (MWh'cap^ $-1 \cdot \mathrm{yr}^{\wedge}-1$ )

\begin{tabular}{|c|c|c|c|}
\hline & TPES & TPEF & TPEF/TPES \\
\hline AUS-2014 & 65.5 & \begin{tabular}{|r|}
81.07 \\
\end{tabular} & $124 \%$ \\
\hline $\mathrm{CHN}-2014$ & 26.11 & 23.45 & $90 \%$ \\
\hline AUS-2000 & 65.5 & 65.13 & $99 \%$ \\
\hline CHN-2000 & 10.56 & 9.23 & $87 \%$ \\
\hline
\end{tabular}

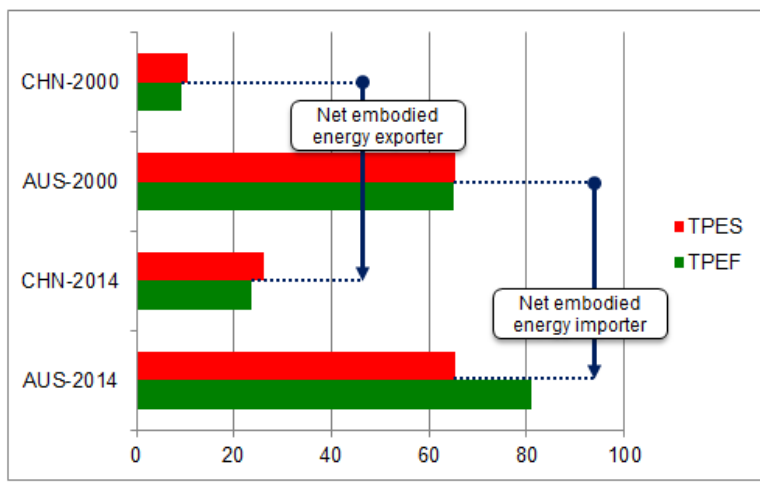

B) Decrease (AUS and CHN) of Decoupling Index, due to percentage increase in energy consumption with TPEF (MWh·cap $\left.{ }^{\wedge}-1 \cdot \mathrm{yr}^{\wedge}-1\right)$

\begin{tabular}{|l|r|r|r|}
\cline { 2 - 4 } \multicolumn{1}{c|}{} & $\mathbf{2 0 0 0}$ & $\mathbf{2 0 1 4}$ & $\mathbf{2 0 1 4 / 2 0 0 0}$ \\
\hline CHN-TPEF & 9.23 & 23.45 & $254 \%$ \\
\hline AUS-TPEF & 65.13 & 81.07 & $124 \%$ \\
\hline CHN-TPES & 10.56 & 26.11 & $247 \%$ \\
\hline AUS-TPES & 65.5 & 62.11 & $95 \%$ \\
\hline
\end{tabular}

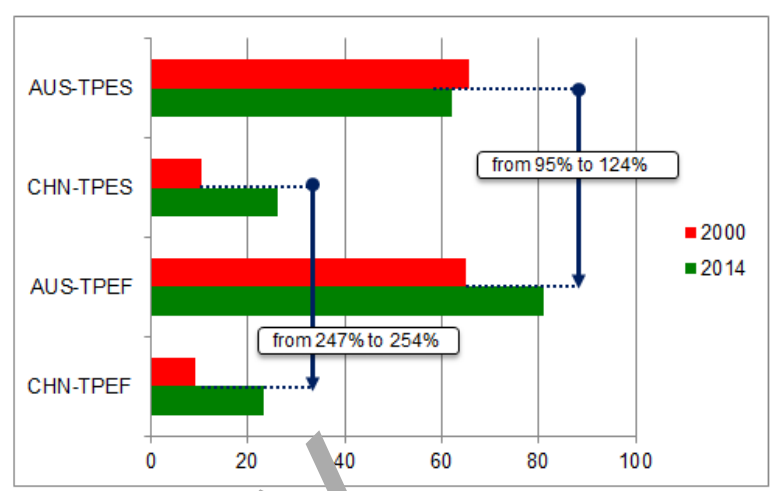

Supplementary Figure 1: Example of how the Decoupling Index (DI) derrease embodied energy exporter countries (CHN) and embodied energy importer countries (AUS). In bot of $t, \mathrm{~s}$, th DI is lower when TPEF accounts are considered instead of TPES ones. This occurs due to a higher re rce tage increase of energy use within TPEF accounts between 2000 and 2014. The figure shows how co ntrie are net embodied energy importers or exporters (a) and how the percentage difference in energy ar ase gre ter in both countries (b) with footprint accol its.

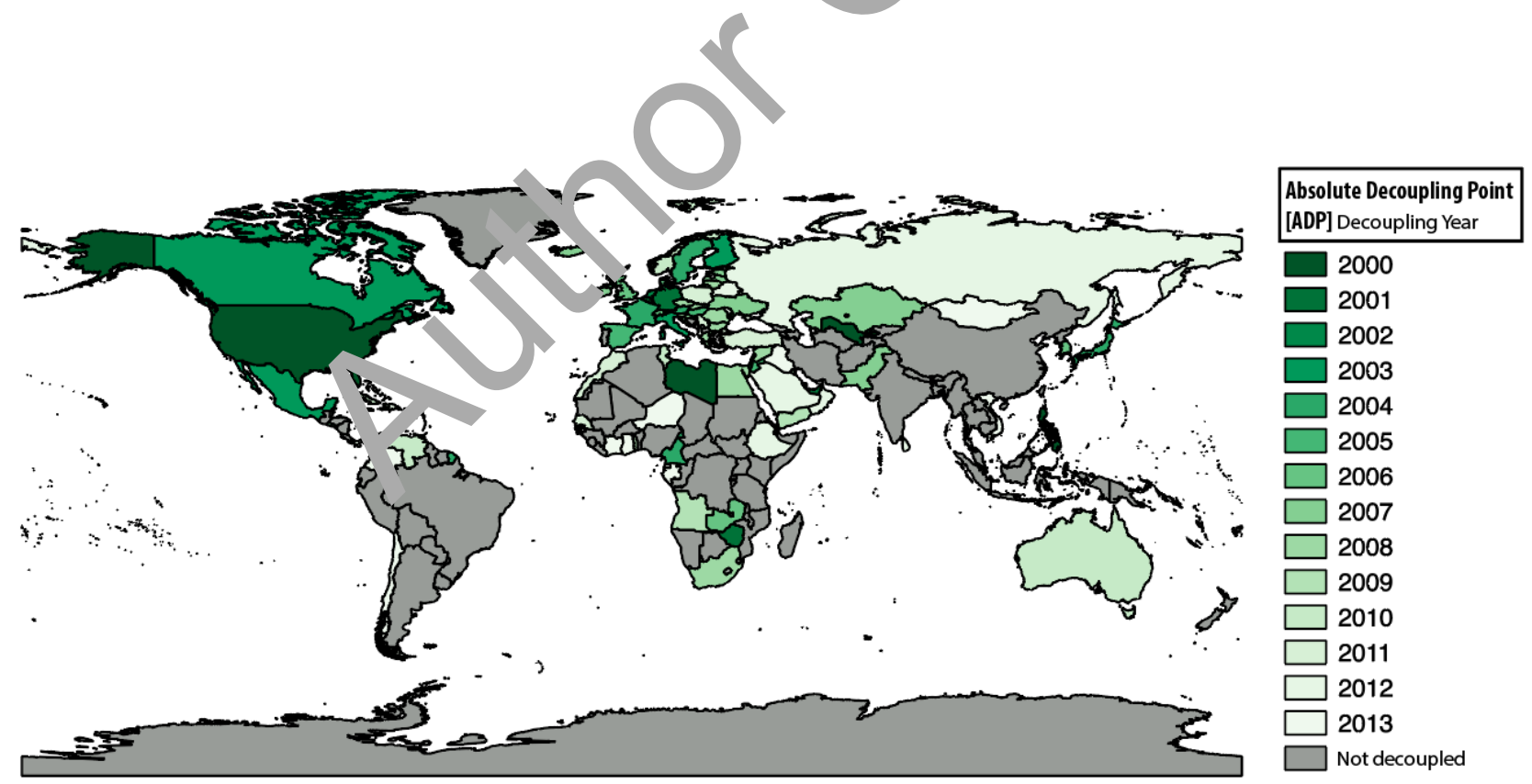

Supplementary Figure 2: 89 countries experienced temporary or permanent decoupling between the year 2000 and 2014. The year that the decoupling was reached is shown in the figure above. 


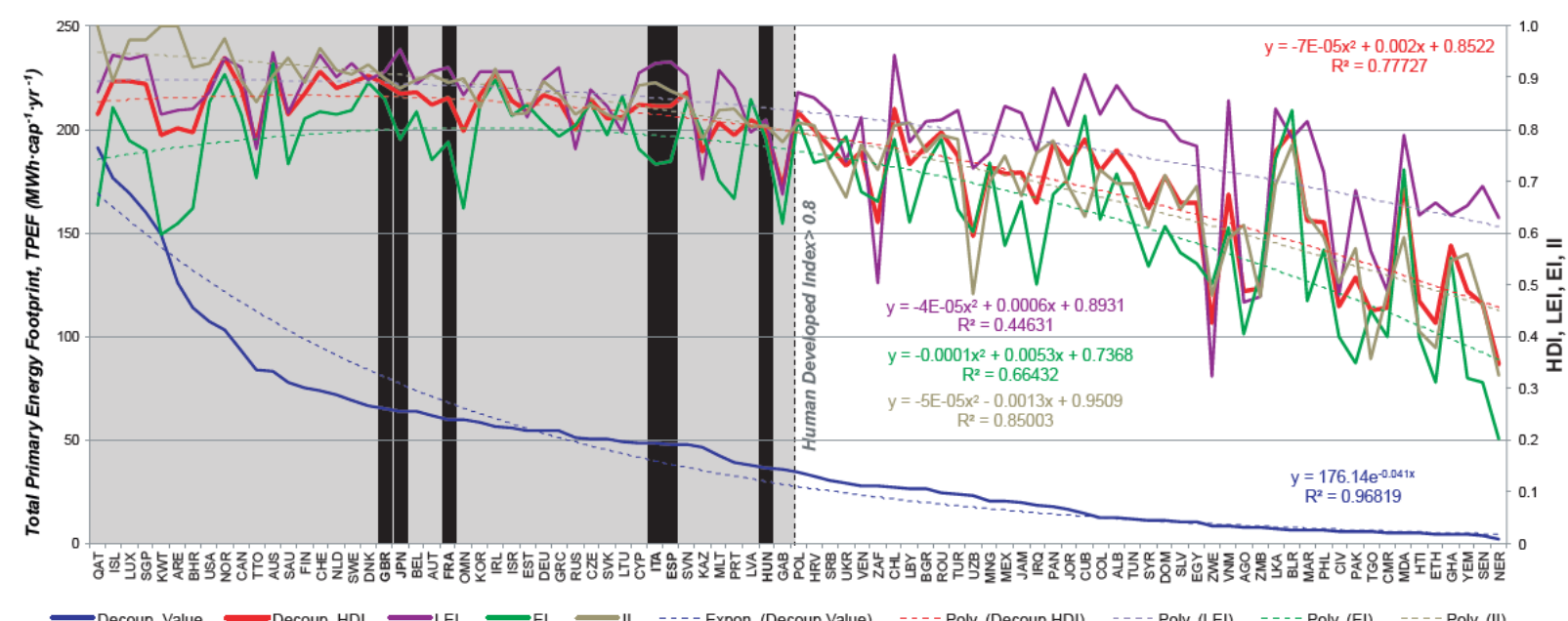

Supplementary Figure 3: The 89 temporarily and permanently decoupled countries (exemplary countries in black lines) ordered from left to right according the higher TPEF where decoupling was achieved (in vertical axis $Y 1$ ). A line has been traced in the value of $0.8 \mathrm{HDI}$, which is understood as the bottom limit of high HDI according to UNDP.

To the left of the line, countries with a higher decoupling than $35 \mathrm{MWh} \cdot \mathrm{cap}^{-1} \cdot \mathrm{yr}^{-1}$ in be found. In order to better understand the characteristics of the 89 decoupling countries, HDI data (in vertical a is Y2) has been disaggregated in Life Expectancy Index (LEI, purple), Education Index (EI, green) and Inco-Indes I, orange). It is observed that while the high II levels of high-TPEF consumer countries are able to me tain, eir d coupling trend, the low EI (below 0.7) of some high-TPEF countries might make sustained decowing diff: ult. On the contrary, high LEI of some medium-low TPEF countries might support their cap city te acr. sve sustained decoupling.

Supplementary Table 2: Decoupling Index values (DI PES and $I_{T P E F}$ ) during the 2000-2014 year period by country and country codes. Countries have been listed from reatest o lowest according their DI $I_{T P E F}$, from the most absolutely decoupled country to the most coupled ones, and unuy the ones where HDI has been reduced. In the rightmost column, Hidden Energy Flow (HEF) has $b \cdot n$ added (HEF =TPEF/TPES-1), which shows the percentage increase/reduction of energy that countries displ $\ldots$ if $l$. 'orted energy embodied in goods and services is taken into account (Akizu et al., 2017). Absolute decouplec coun ies have been identified in green, relatively decoupled ones in orange, coupled countries in red and countring w. IDI value has decreased in grey. Negative HEF countries have

\begin{tabular}{|c|c|c|c|c|}
\hline Country & Code & TPE & $\begin{array}{c}\text { DI_TPEF } \\
(2000-2014)\end{array}$ & $\begin{array}{c}\text { HEF } \\
\text { (Average 2000-2014) }\end{array}$ \\
\hline Bahrain & $\mathrm{BHR}$ & 162.89 & 168.73 & $-23 \%$ \\
\hline Belgium & BEL & 171.55 & 168.30 & $-3 \%$ \\
\hline USA & USA & 164.25 & 164.68 & $14 \%$ \\
\hline UAE & ARE & 167.92 & 163.76 & $4 \%$ \\
\hline Jamaica & JAM & 167.17 & 160.55 & $20 \%$ \\
\hline Israel & ISR & 129.90 & 157.16 & $42 \%$ \\
\hline UK & GBR & 169.69 & 156.66 & $50 \%$ \\
\hline Japan & JPN & 160.31 & 156.56 & $30 \%$ \\
\hline Cyprus & CYP & 164.55 & 155.57 & $70 \%$ \\
\hline Italy & ITA & 162.12 & 155.33 & $30 \%$ \\
\hline France & FRA & 155.50 & 152.88 & $19 \%$ \\
\hline Uzbekistan & UZB & 150.93 & 150.73 & $-8 \%$ \\
\hline Portugal & PRT & 153.92 & 150.12 & $34 \%$ \\
\hline Ireland & $\mathrm{IRL}$ & 162.83 & 150.01 & $36 \%$ \\
\hline Greece & GRC & 152.34 & 148.79 & $62 \%$ \\
\hline Spain & ESP & 158.89 & 146.47 & $23 \%$ \\
\hline Zimbabwe & ZWE & 123.56 & 145.56 & $-13 \%$ \\
\hline Jordan & JOR & 117.83 & 145.55 & $23 \%$ \\
\hline Malta & MLT & 62.74 & 136.92 & $75 \%$ \\
\hline Germany & DEU & 135.90 & 134.49 & $12 \%$ \\
\hline Denmark & DNK & 158.18 & 131.12 & $52 \%$ \\
\hline Cameroon & CMR & 134.38 & 130.81 & $7 \%$ \\
\hline
\end{tabular}




\begin{tabular}{|c|c|c|c|c|}
\hline Philippines & $\mathrm{PHL}$ & 127.84 & 130.25 & $3 \%$ \\
\hline Sweden & SWE & 153.51 & 129.10 & $5 \%$ \\
\hline Hungary & HUN & 122.86 & 108.89 & $9 \%$ \\
\hline Mexico & MEX & 71.57 & 99.02 & $5 \%$ \\
\hline Cuba & CUB & 129.54 & 97.54 & $14 \%$ \\
\hline Ethiopia & ETH & 85.58 & 86.77 & $-22 \%$ \\
\hline Mozambique & MOZ & 78.80 & 80.44 & $5 \%$ \\
\hline Luxembourg & LUX & 155.17 & 78.79 & $64 \%$ \\
\hline Zambia & ZMB & 78.74 & 77.99 & $3 \%$ \\
\hline $\begin{array}{l}\text { Dominican } \\
\text { Republic }\end{array}$ & DOM & 143.77 & 77.40 & $8 \%$ \\
\hline Belarus & BLR & 42.21 & 74.48 & $-81 \%$ \\
\hline Pakistan & PAK & 77.69 & 73.36 & $-10 \%$ \\
\hline Togo & TGO & 61.03 & 68.92 & $1 \%$ \\
\hline Niger & NER & 66.41 & 67.22 & $16 \%$ \\
\hline Tanzania & TZA & 57.69 & 66.54 & $-2 \%$ \\
\hline El Salvador & SLV & 112.57 & 64.53 & $23 \%$ \\
\hline Ukraine & UKR & 142.38 & 62.35 & $-21 \%$ \\
\hline Slovenia & SVN & 87.28 & 59.62 & $5 \%$ \\
\hline Senegal & SEN & 67.17 & 50.36 & $18 \%$ \\
\hline Venezuela & VEN & 71.32 & 49.65 & $-4 \%$ \\
\hline Angola & AGO & 55.48 & 49.18 & $5 \%$ \\
\hline Finland & FIN & 102.31 & 45.99 & $-8 \%$ \\
\hline Austria & AUT & 50.28 & 43.92 & $31 \%$ \\
\hline Azerbaijan & AZE & 68.62 & 41.63 & $-8 \%$ \\
\hline Kenya & KEN & 56.34 & J.76 & $11 \%$ \\
\hline Nepal & NPL & 49.53 & 70.51 & $7 \%$ \\
\hline Croatia & HRV & 88.91 & 91 & $20 \%$ \\
\hline DR Congo & COD & 41.70 & 39.88 & $4 \%$ \\
\hline Canada & CAN & 125.90 & 39.09 & $-3 \%$ \\
\hline Switzerland & $\mathrm{CHE}$ & $155.0 ?$ & 38.06 & $80 \%$ \\
\hline Slovakia & SVK & 136.2 & 37.87 & $22 \%$ \\
\hline Botswana & BWA & $x^{11}$ & 37.35 & $88 \%$ \\
\hline Ghana & $\mathrm{GHA}$ & 86.6 & 37.20 & $2 \%$ \\
\hline Serbia & SRB & 92 & 35.50 & $7 \%$ \\
\hline Singapore & SGP & 0.11 & 35.44 & $131 \%$ \\
\hline Cambodia & $\mathrm{KHM}$ & 36.16 & 35.01 & $10 \%$ \\
\hline Czech Republic & CZE & 105.72 & 32.97 & $-1 \%$ \\
\hline Nicaragua & $\mathrm{NIC}$ & 30.27 & 32.49 & $15 \%$ \\
\hline Bolivia & $\mathrm{BOL}$ & 17.18 & 32.04 & $-8 \%$ \\
\hline Benin & BEN & 26.15 & 31.40 & $7 \%$ \\
\hline Myanmar & MMR & 41.17 & 30.82 & $-3 \%$ \\
\hline Cote dlvoire & CIV & 19.30 & 29.72 & $-14 \%$ \\
\hline Tunisia & TUN & 22.66 & 28.13 & $5 \%$ \\
\hline Bulgaria & BGR & 53.54 & 27.72 & $-21 \%$ \\
\hline Netherlands & NLD & 150.31 & 26.95 & $13 \%$ \\
\hline Paraguay & PRY & 51.74 & 26.63 & $29 \%$ \\
\hline Morocco & MAR & 25.84 & 26.13 & $-7 \%$ \\
\hline Turkey & TUR & 28.35 & 26.01 & $26 \%$ \\
\hline India & IND & 25.10 & 25.79 & $-5 \%$ \\
\hline Guatemala & GTM & 24.04 & 25.68 & $12 \%$ \\
\hline South Africa & ZAF & 27.54 & 25.25 & $-16 \%$ \\
\hline Poland & $\mathrm{POL}$ & 52.75 & 24.01 & $8 \%$ \\
\hline Yemen & YEM & 62.21 & 23.46 & $-1 \%$ \\
\hline Indonesia & IDN & 34.00 & 23.17 & $-10 \%$ \\
\hline Romania & $\mathrm{ROU}$ & 96.40 & 22.66 & $0 \%$ \\
\hline Russia & RUS & 34.40 & 22.25 & $-17 \%$ \\
\hline Mauritius & MUS & 27.26 & 22.16 & $75 \%$ \\
\hline
\end{tabular}




\begin{tabular}{|c|c|c|c|c|}
\hline South Korea & KOR & 16.70 & 21.75 & $0 \%$ \\
\hline New Zealand & NZL & 60.55 & 19.53 & $8 \%$ \\
\hline Argentina & ARG & 18.50 & 19.19 & $3 \%$ \\
\hline Egypt & EGY & 17.09 & 19.10 & $1 \%$ \\
\hline Namibia & NAM & 19.19 & 18.48 & $79 \%$ \\
\hline Bangladesh & $B G D$ & 20.82 & 18.03 & $4 \%$ \\
\hline Honduras & HND & 19.98 & 17.58 & $7 \%$ \\
\hline Brazil & BRA & 14.56 & 17.51 & $1 \%$ \\
\hline Colombia & $\mathrm{COL}$ & 43.70 & 17.51 & $31 \%$ \\
\hline Norway & NOR & 139.48 & 16.86 & $30 \%$ \\
\hline Sri Lanka & LKA & 36.20 & 15.96 & $0 \%$ \\
\hline Iceland & ISL & 7.05 & 15.88 & $-9 \%$ \\
\hline Panama & PAN & 18.01 & 15.71 & $35 \%$ \\
\hline Estonia & EST & 16.08 & 15.52 & $5 \%$ \\
\hline Albania & ALB & 21.04 & 15.12 & $28 \%$ \\
\hline Lithuania & LTU & 34.47 & 14.75 & $36 \%$ \\
\hline Chile & $\mathrm{CHL}$ & 24.35 & 14.68 & $-4 \%$ \\
\hline Tajikistan & TJK & 100.01 & 14.00 & $-1 \%$ \\
\hline Latvia & LVA & 21.70 & 13.84 & $37 \%$ \\
\hline Kazakhstan & $\mathrm{KAZ}$ & 10.51 & 13.82 & $-14 \%$ \\
\hline Algeria & $\mathrm{DZA}$ & 16.29 & 13.61 & $-32 \%$ \\
\hline Iran & IRN & 14.54 & 13.23 & $0 \%$ \\
\hline Ecuador & ECU & 20.37 & 12.34 & $13 \%$ \\
\hline Armenia & ARM & 15.28 & 12.33 & $18 \%$ \\
\hline Saudi Arabia & SAU & 16.39 & $1^{1} \ldots$ & $-8 \%$ \\
\hline Costa Rica & $\mathrm{CRI}$ & 13.04 & 11.48 & $22 \%$ \\
\hline Moldova & MDA & 45.37 & 1.25 & $-71 \%$ \\
\hline Congo & $\mathrm{COG}$ & 8.29 & 16. & $12 \%$ \\
\hline Thailand & THA & 10.85 & 9.90 & $-14 \%$ \\
\hline Australia & AUS & 140.74 & 9.80 & $13 \%$ \\
\hline Mongolia & MNG & 16.3 & 9.44 & $-14 \%$ \\
\hline Oman & OMN & 8.6 & 9.38 & $-25 \%$ \\
\hline Viet Nam & VNM & 10. & 9.28 & $-10 \%$ \\
\hline Georgia & GEO & 9.84 & 9.21 & $35 \%$ \\
\hline Haiti & $\mathrm{HTI}$ & 8.99 & 9.14 & $3 \%$ \\
\hline China & $\mathrm{CHN}$ & 9.26 & 8.85 & $-14 \%$ \\
\hline Kyrgyzstan & $K G Z$ & 17.28 & 8.41 & $-2 \%$ \\
\hline Malaysia & MYS & 11.90 & 8.30 & $-28 \%$ \\
\hline Uruguay & URY & 8.27 & 8.08 & $45 \%$ \\
\hline Peru & PER & 8.04 & 6.57 & $17 \%$ \\
\hline Qatar & QAT & 83.22 & 5.63 & $-23 \%$ \\
\hline Gabon & GAB & 4.36 & 5.40 & $6 \%$ \\
\hline Kuwait & KWT & 138.41 & 5.15 & $13 \%$ \\
\hline $\begin{array}{l}\text { Trinidad and } \\
\text { Tobago }\end{array}$ & TTO & 5.93 & 4.28 & $-50 \%$ \\
\hline Iraq & IRQ & 13.74 & 3.46 & $-7 \%$ \\
\hline Syria & SYR & -171.36 & -168.37 & $-13 \%$ \\
\hline Libya & LBY & -145.06 & -175.20 & $-42 \%$ \\
\hline
\end{tabular}

